\title{
Prioritisation of potential anti-SARS-CoV-2 drug repurposing opportunities based on ability to achieve adequate plasma and target site concentrations derived from their established human pharmacokinetics
}

\begin{abstract}
Usman Arshad ${ }^{1}$, Henry Pertinez ${ }^{1}$, Helen Box ${ }^{1}$, Lee Tatham ${ }^{1}$, Rajith KR Rajoli ${ }^{1}$, Paul Curley ${ }^{1}$, Megan Neary ${ }^{1}$, Joanne Sharp ${ }^{1}$, Neill J Liptrott ${ }^{1}$, Anthony Valentijn ${ }^{1}$, Christopher David ${ }^{1}$, Steve P Rannard ${ }^{2}$, Paul $\mathrm{O}^{\prime}$ Neill $^{2}$, Ghaith Aljayyoussi ${ }^{3}$, Shaun Pennington ${ }^{3}$, Stephen A Ward ${ }^{3}$, David J Back ${ }^{1}$, Saye H Khoo ${ }^{1}$, Patrick G Bray ${ }^{4}$. Giancarlo Biagini ${ }^{3}$, Andrew Owen ${ }^{1}$.
\end{abstract}

${ }^{1}$ Department of Molecular and Clinical Pharmacology, University of Liverpool, Liverpool, L7 3NY, UK

${ }^{2}$ Department of Chemistry, University of Liverpool, Liverpool, L69 3BX, UK

${ }^{3}$ Centre for Drugs and Diagnostics. Liverpool School of Tropical Medicine, Liverpool L3 5QA, UK

${ }^{4}$ Pat Bray Electrical, 260D Orrell Road, Orrell, Wigan, WN5 8QZ, UK

\section{Author for correspondence:}

Professor Andrew Owen

Department of Molecular and Clinical Pharmacology

Materials Innovation Factory

University of Liverpool

51 Oxford Street,

Liverpool L7 3NY

United Kingdom

aowen@liverpool.ac.uk 
medRxiv preprint doi: https://doi.org/10.1101/2020.04.16.20068379; this version posted April 22, 2020. The copyright holder for this preprint (which was not certified by peer review) is the author/funder, who has granted medRxiv a license to display the preprint in perpetuity.

All rights reserved. No reuse allowed without permission.

\section{Abstract}

There is a rapidly expanding literature on the in vitro antiviral activity of drugs that may be repurposed for therapy or chemoprophylaxis against SARS-CoV-2. However, this has not been accompanied by a comprehensive evaluation of the ability of these drugs to achieve target plasma and lung concentrations following approved dosing in humans. Moreover, most publications have focussed on $50 \%$ maximum effective concentrations $\left(\mathrm{EC}_{50}\right)$, which may be an insufficiently robust indicator of antiviral activity because of marked differences in the slope of the concentration-response curve between drugs. Accordingly, in vitro anti-SARS-CoV-2 activity data was digitised from all available publications up to $13^{\text {th }} \mathrm{April} 2020$ and used to recalculate an $\mathrm{EC}_{90}$ value for each drug. $E C_{90}$ values were then expressed as a ratio to the achievable maximum plasma concentrations ( $\mathrm{Cmax}$ ) reported for each drug after administration of the approved dose to humans ( $\mathrm{Cmax} / \mathrm{EC}_{90}$ ratio). Only 14 of the 56 analysed drugs achieved a $\mathrm{Cmax} / \mathrm{EC}_{90}$ ratio above 1 meaning that plasma $\mathrm{Cmax}$ concentrations exceeded those necessary to inhibit $90 \%$ of SARS-CoV-2 replication. A more in-depth assessment of the putative agents tested demonstrated that only nitazoxanide, nelfinavir, tipranavir (boosted with ritonavir) and sulfadoxine achieved plasma concentrations above their reported anti-SARS-CoV-2 activity across their entire approved dosing interval at their approved human dose. For all drugs reported, the unbound lung to plasma tissue partition coefficient $\left(\mathrm{K}_{\mathrm{p}} \mathrm{U}_{\text {lung }}\right)$ was also simulated and used along with reported $\mathrm{Cmax}$ and fraction unbound in plasma to derive a lung $\mathrm{Cmax} / \mathrm{EC}_{50}$ as a better indicator of potential human efficacy (lung $\mathrm{Cmax}_{\mathrm{E}} \mathrm{EC}_{90}$ ratio was also calculable for a limited number of drugs). Using this parameter hydroxychloroquine, chloroquine, mefloquine, atazanavir (boosted with ritonavir), tipranavir (boosted with ritonavir), ivermectin, azithromycin and lopinavir (boosted with ritonavir) were all predicted to achieve lung concentrations over 10-fold higher than their reported $\mathrm{EC}_{50}$. This analysis was not possible for nelfinavir because insufficient data were available to calculate $\mathrm{K}_{\mathrm{p}} \mathrm{U}_{\text {lung }}$ but nitozoxanide and sulfadoxine were also predicted to exceed their reported $\mathrm{EC}_{50}$ by 3.1- and 1.5-fold in lung, respectively. The antiviral activity data reported to date have been acquired under different laboratory conditions across multiple groups, applying variable levels of stringency. However, this analysis may be used to select potential candidates for further clinical testing, while deprioritising compounds which are unlikely to attain target concentrations for antiviral activity. Future studies should focus on $\mathrm{EC}_{90}$ values and discuss findings in the context of achievable exposures in humans, especially within target compartments such as the lung, in order to maximise the potential for success of proposed human clinical trials. 
medRxiv preprint doi: https://doi.org/10.1101/2020.04.16.20068379; this version posted April 22, 2020. The copyright holder for this preprint (which was not certified by peer review) is the author/funder, who has granted medRxiv a license to display the preprint in perpetuity.

All rights reserved. No reuse allowed without permission.

\section{Introduction}

Coronavirus 2019 (COVID-19) is a respiratory disease caused by severe acute respiratory syndrome coronavirus 2 (SARS-CoV-2) infection. Fever, a persistent cough and respiratory symptoms are common, with some patients reporting vomiting, nausea, abdominal pains and diarrhoea [1]. To date, no specific treatment is available, and this has resulted in significant morbidity and mortality globally. According to the International Clinical Trials Registry Platform search portal, 927 clinical trials for COVID-19 have been registered [2]. This rapidly expanding pandemic warrants the urgent development of strategies, particularly to protect people at high risk of infection. Repurposing currently available drugs that have been utilised clinically with a known safety profile, is the quickest way to address this serious unmet clinical need. Antiviral drugs are urgently required for treatment of patients with mild/moderate disease to prevent the worsening of symptoms and reduce the burden upon healthcare systems. However, a different approach is likely to be needed for patients that are already in a critical state, due to the immune dysregulation which is so apparent in severe cases [3].

Previous investigations have shown that the entry by SARS-CoV occurs via the angiotensin converting enzyme 2 (ACE2) receptor [4]. A study on normal lung tissue showed that $83 \%$ of ACE2-expressing cells were alveolar epithelial type II cells [5], highlighting the lungs as the primary target organ that facilitate viral invasion and replication. Furthermore, the ACE2 receptor is also highly expressed in gastrointestinal epithelial cells, with SARS-CoV-2 RNA observed to be present in stool specimens of patients during infection $[1,6]$. A recent retrospective analysis of 85 patients with laboratory confirmed COVID-19 also indicated that SARS-CoV-2 infects human kidney tubules and induces acute tubular damage in some patients [7]. Furthermore, $2-11 \%$ of patients with COVID-19 exhibit liver comorbidities [8]. Of note is an observation of SARS and Middle East respiratory syndrome (MERS) having a tropism to the gastrointestinal tract [9] and causing liver impairments in addition to respiratory disease. The genomic similarity between SARS-CoV-2 and SARS-CoV (79.6\% sequence identity) would imply that the current virus would act in a similar manner and be present within the body systemically [10-12]. Therefore, treatment options that provide therapeutic concentrations of drug(s) within the systemic circulation and other affected organs are likely to be required.

In the absence of a vaccine, antiviral drugs could also be deployed as chemoprophylaxis to protect against infection and would present an essential tool for protecting healthcare staff and other key workers, as well as household contacts of those already infected. For chemoprevention drugs will need to penetrate into the multiple sites where SARS-CoV-2 infection occurs, and do so in sufficient concentrations to inhibit viral replication [13]. This may include the mucous membranes present in the nasal cavity and throat, the ocular surface, tears and the upper respiratory tract/lungs $[14,15]$. 
medRxiv preprint doi: https://doi.org/10.1101/2020.04.16.20068379; this version posted April 22, 2020. The copyright holder for this preprint (which was not certified by peer review) is the author/funder, who has granted medRxiv a license to display the preprint in perpetuity.

All rights reserved. No reuse allowed without permission.

However, therapeutic concentrations may not be needed in the systemic circulation for chemoprophylaxis, but this is yet to be determined. Although difficult and scarcely studied, work in animals has shown that the size of the inoculum of other respiratory viruses such as influenza is associated with the severity of the resultant disease $[16,17]$. Reports with SARS-CoV-2 indicate that higher viral loads are indicative of poorer prognosis and correlate with the severity of symptoms, with viral load in severe cases reported to be 60 times higher than that of mild cases $[18,19]$. In light of this, even if a chemoprophylactic drug reduced inoculum size without completely blocking transmission, major benefits for morbidity and mortality may still be achievable.

Many ongoing global research efforts are focused on screening the activity of existing compounds in vitro in order to identify candidates to repurpose for SARS-CoV-2. However, current data have not yet been systematically analysed in the context of the plasma and target site exposures that are achievable after administration of the approved doses to humans. The purpose of this work was to evaluate the existing in vitro anti-SARS-CoV-2 data to determine and prioritise drugs capable of reaching antiviral concentrations within the blood plasma. An accepted physiologically-based pharmacokinetic (PBPK) equation was also used to predict the expected concentration in lung, in order to assess the potential of these drugs for therapy in this key disease site and the potential for chemoprevention. 
medRxiv preprint doi: https://doi.org/10.1101/2020.04.16.20068379; this version posted April 22, 2020. The copyright holder for this preprint

(which was not certified by peer review) is the author/funder, who has granted medRxiv a license to display the preprint in perpetuity.

All rights reserved. No reuse allowed without permission.

\section{Methods}

\section{Candidate Analysis}

To identify compounds and their relevant potency and pharmacokinetic data, we performed a literature search on PubMed, Google Scholar, BioRxiv, MedRxiv, and ChemRxiv. The following search terms were used for in vitro activity data - (COVID-19 OR SARS-CoV-2) AND (EC50 OR IC50 OR antiviral). For pharmacokinetic data (Cmax OR pharmacokinetics) was used along with the drug name for drugs with reported anti-SARS-CoV-2 activity (up to April $13^{\text {th }}$ 2020). Further clinical pharmacokinetic data was obtained from the Food and Drug Administration (FDA), the European Medicines Agency (EMA) and through publications available online.

\section{Lung accumulation prediction}

An indication of the degree to which candidate drugs are expected to accumulate in lung (a presumed site of primary efficacy and for prevention of SARS-CoV-2 infection) was provided by calculation of unbound lung to plasma tissue partition coefficient $\left(\mathrm{K}_{\mathrm{p}} \mathrm{U}_{\text {lung }}\right)$ according to the methodology of Rodgers and Rowland [20-22]. The formulae provided in these methods use the physicochemical properties of the drug (pKa, log P, classification as acid/base/neutral) and in vitro drug binding information (fraction unbound in plasma, blood to plasma ratio), in combination with tissue specific data (lipid content, volumes of intra/extracellular water etc.) to predict tissue $\mathrm{K}_{\mathrm{p}} \mathrm{U}$ values. Predicted $\mathrm{K}_{\mathrm{p}} \mathrm{U}_{\text {lung }}$ was converted to $K_{p_{\_} \text {lung }}$ by multiplying by fraction unbound in plasma to allow estimation of lung exposure from in vivo measurements of plasma concentration. In the absence of observed tissue distribution data the Rodgers and Rowland method is an accepted means to provide initial estimates of tissue partitioning for PBPK modelling, but with known limits on potential accuracy (generally predicted $K_{p} U$ is within 23 fold of observed tissue $K_{p} U$ values).

\section{Data analysis and interpretation}

Since in the majority of papers only an $\mathrm{EC}_{50}$ value was available, concentration-response data were digitized using the Web Plot Digitizer ${ }^{\circledR}$ software. Graphs were then re-plotted in SigmaPlot 14.0 (Systat Software, Inc.) and curves were fitted to confirm $\mathrm{EC}_{50}$ values and determine $\mathrm{EC}_{90}$ values. $\mathrm{A} \mathrm{Cmax} / \mathrm{EC}_{50}$ and $\mathrm{Cmax} / \mathrm{EC}_{90}$ ratio was then calculated for each drug for which previous evidence of clinical use in humans and availability of human pharmacokinetic data were available. Lung $\mathrm{K}_{\mathrm{p}} \mathrm{U}$ values were also used in combination with reported $\mathrm{Cmax}$ values to derive an estimate of lung exposure at $\mathrm{Cmax}$ for 
medRxiv preprint doi: https://doi.org/10.1101/2020.04.16.20068379; this version posted April 22, 2020. The copyright holder for this preprint (which was not certified by peer review) is the author/funder, who has granted medRxiv a license to display the preprint in perpetuity. All rights reserved. No reuse allowed without permission.

each drug. For a subset of molecules, the absence of available physicochemical or plasma protein binding parameters prohibited derivation of a $\mathrm{K}_{\mathrm{p}} \mathrm{U}$ estimate. For the remaining drugs, a lung $\mathrm{Cmax} / \mathrm{EC}_{50}$ and lung $\mathrm{Cmax}_{\mathrm{E}} \mathrm{EC}_{90}$ was calculated. Published plasma concentration - time data for the most promising candidates were also digitized (were available) and replotted to visually represent human pharmacokinetics relative to the calculated $\mathrm{EC}_{50}$ and $\mathrm{EC}_{90}$ data. 
medRxiv preprint doi: https://doi.org/10.1101/2020.04.16.20068379; this version posted April 22, 2020. The copyright holder for this preprint (which was not certified by peer review) is the author/funder, who has granted medRxiv a license to display the preprint in perpetuity.

All rights reserved. No reuse allowed without permission.

\section{Results}

\section{Identified papers and methods}

We identified 14 key studies that detailed the antiviral activity of 72 compounds [23-37]. The majority of the in vitro SARS-CoV-2 infection experiments were performed in Vero E6 cells (ATCC 1586) maintained in either DMEM or MEM. Other studies utilised Vero-hSLAM cells, VeroE6 cells expressing TMPRSS2 and the CACO-2 cell line to cultivate the virus. The following SARS-CoV-2 strains were used across studies; WA-1 strain - BEI \#NR-52281; Brazil/RJ-314/2020; C-Tan-nCoV Wuhan strain 01; Wuhan/WIV04/2019; USA-WA1/2020; nCoV-2019BetaCoV/Wuhan/WIV04/2019; BetaCoV/Hong Kong/VM20001061/2020; Australia/VIC01/2020; ßCoV/KOR/KCDC03/2020 and BavPat1/2020. Cells across all studies were infected with the virus with a multiplicity of infection (MOI) of $0.002,0.01$, $0.0125,0.02,0.05$ and 0.1 . Drugs were added at concentrations varying between $0.01 \mu \mathrm{M}-500 \mu \mathrm{M}$. A summary of the differences in methodologies between studies reporting SARS-CoV-2 antiviral activity is presented in Table 1.

\section{Identification of candidates achieving plasma concentrations expected to exert antiviral activity (Cmax / $\mathrm{EC}_{50}$ ratio)}

Seventeen molecules had a reported $\mathrm{Cmax}$ value greater than at least one of the reported $\mathrm{EC}_{50}$ values against SARS-CoV-2 and these included nelfinavir, chloroquine, remdesivir, lopinavir (boosted with ritonavir), eltrombopag, hydroxychloroquine, atazanavir (boosted with ritonavir), indomethacin, favipiravir, sulfadoxine, nicolsamide, mefloquine, tipranavir (boosted with ritonavir), ritonavir, merimepodib, anidulafungin and nitazoxanide. However, it should be noted that for amodiaquine, atazanavir, chloroquine, hydroxychloroquine, lopinavir, mefloquine, nelfinavir, remdesevir and toremefine, more than one $\mathrm{EC}_{50}$ value had been reported across the available literature and these were not always in agreement (Figure $1 \mathrm{~A}$ ). Moreover, this variability in reported $\mathrm{EC}_{50}$ values sometimes resulted in $\mathrm{Cmax}_{\mathrm{N}} \mathrm{EC}_{50}$ ratios giving a different estimation of the likely value of the molecule. Meaning that for the same drug, the $\mathrm{Cmax}_{\text {/ }} \mathrm{EC}_{50}$ ratio could be above or below 1 (Figure 1B). For amodiaquine and toremifene all reported $\mathrm{EC}_{50}$ values were below their reported $\mathrm{Cmax}$ and only for nelfinavir was the reported Cmax expected to exceed both reported $\mathrm{EC}_{50}$ values. For atazanavir, chloroquine, hydroxychloroquine, lopinavir, mefloquine and remdesivir, some $\mathrm{EC}_{50}$ values were above the Cmax whereas other were below. This observation dramatically highlights the sensitivity of the current analysis to the reported antiviral activity data, and this should be taken into account when interpreting the data presented hereafter. 
medRxiv preprint doi: https://doi.org/10.1101/2020.04.16.20068379; this version posted April 22, 2020. The copyright holder for this preprint (which was not certified by peer review) is the author/funder, who has granted medRxiv a license to display the preprint in perpetuity.

All rights reserved. No reuse allowed without permission.

Identification of candidates achieving plasma concentrations exceeding the SARS-CoV-2 EC 90 (Cmax / $\mathrm{EC}_{90}$ ratio)

For 57 of the reported antiviral activities, data covering a sufficient concentration range were available for digitisation and subsequent calculation of an $\mathrm{EC}_{90}$ value. For the remainder it was not possible to calculate an $\mathrm{EC}_{90}$. Drugs with an available $\mathrm{EC}_{90}$ were ranked according to their $\mathrm{Cmax} \mathrm{EC}_{90}$ ratio (Figure 2). Drugs with a value above 1.0 achieved plasma concentrations above the concentrations reported to inhibit $90 \%$ of SARS-CoV-2 replication. Only eltrombopag, favipiravir, remdesevir, nelfinavir, niclosamide, nitazoxanide and tipranavir were estimated to exceed at least one of their reported $\mathrm{EC}_{90}$ by 2 -fold or more at Cmax concentrations. Anidulafungin, lopinavir, chloroquine and ritonavir were also reported to exceed at least one of their reported $\mathrm{EC}_{90}$ values at $\mathrm{Cmax}$ but by less than 2 -fold.

\section{Detailed interrogation of the plasma pharmacokinetics in relation to reported anti-SARS-CoV-2 activity}

For drugs with $\mathrm{Cmax}$ concentrations above at least one of their reported $\mathrm{EC}_{90}$ values that are not already in clinical trials for Covid-19, a detailed evaluation of concentrations across their approved dosing interval was undertaken. For this, published pharmacokinetics data were digitised and replotted relative to the calculated $\mathrm{EC}_{50}$ and $\mathrm{EC}_{90}$ data for SARS-CoV-2 (Figure 3). For tipranavir (boosted with ritonavir), nelfinavir, sulfadoxine and nitazoxanide plasma concentrations after administration of the approved dose remained above SARS-CoV-2 effective concentrations across the entire dosing interval. For antifungdalin, etrombopag, lopinavir (boosted with ritonavir), mefloquine and chloroquine, $\mathrm{Cmax}$ values were above $\mathrm{EC}_{90}$ at $2,6,8$, and 24 hours post dose respectively, but concentrations would be expected to dip below the $\mathrm{EC}_{50}$ at 3, 8, 10, 72 and 120 hours post dose respectively when given at approved doses and schedules. An overview of these drugs is presented in Figure 2.

\section{Simulated lung exposure relative to reported anti-SARS-CoV-2 activity}

Lung $\mathrm{KpU}$ was simulated for all molecules for which the necessary physicochemical properties and in vitro drug binding information were available. $\mathrm{KpUlung}$ was then used along with fraction unbound in plasma ( $\mathrm{Fu}$ ) and plasma $\mathrm{Cmax}$ values to calculate a predicted $\mathrm{Cmax} / \mathrm{EC}_{50}$ (Figure 3 ) and $\mathrm{Cmax} / \mathrm{EC}_{90}$ in lung (data not shown). For 4 drugs, ebselen, merimepodib, niclosamide and remdesivir, the fraction 
medRxiv preprint doi: https://doi.org/10.1101/2020.04.16.20068379; this version posted April 22, 2020. The copyright holder for this preprint (which was not certified by peer review) is the author/funder, who has granted medRxiv a license to display the preprint in perpetuity. All rights reserved. No reuse allowed without permission.

unbound data were unavailable. For 6 other drugs, benztropine, indinavir, loperamide, nelfinavir, saquinavir and toremifene the blood to plasma ratios were unavailable. For a further 4 drugs, camostat, emetine, fluspirilene and umifenovir both fraction unbound and blood to plasma ratios were unavailable. Therefore, these drugs were excluded from the analysis. A total of 23 drugs with available data were predicted to give concentrations in lung above at least one of their reported $\mathrm{EC}_{50}$ against SARS-CoV-2 (Figure 4) and 8 of these were predicted to exceed their $\mathrm{EC}_{50}$ by more than 10fold. The rank order of lung $\mathrm{Cmax} / \mathrm{EC}_{90}$ ratio was chloroquine > atazanavir (boosted with ritonavir) > tipranavir (boosted with ritonavir) > hydroxychloroquine $>$ mefloquine $>$ ivermectin $>$ lopinavir (boosted with ritonavir) $>$ azithromycin $>$ ritonavir $>$ gilteritinib $>$ nitazoxanide $>$ imantinib $>$ oxprenolol (data excluded due to this analysis only being possible for 33 of the 56 drugs). 
medRxiv preprint doi: https://doi.org/10.1101/2020.04.16.20068379; this version posted April 22, 2020. The copyright holder for this preprint (which was not certified by peer review) is the author/funder, who has granted medRxiv a license to display the preprint in perpetuity.

All rights reserved. No reuse allowed without permission.

\section{Discussion}

The systematic development of mechanism-based inhibitors for key targets involved in viral replication or pathogenesis is likely to result in highly effective and safe medicines in the coming years. However, the repurposing of already approved medicines in antiviral treatment or chemoprevention strategies is undoubtedly the fastest way to bring forward therapeutic options against the urgent unmet need posed by SARS-CoV-2. A range of different drugs and drug classes have been demonstrated to display varying degrees of antiviral activity against SARS-CoV-2 in vitro, and many of these drugs are already licenced for use in humans for a range of indications. However, currently the data emerging from global screening efforts are not being routinely benchmarked and prioritised against achievable concentrations after administration of doses proven to have acceptable safety profiles in humans.

The current analysis indicates that only 12 drugs with reported antiviral activity are likely to achieve plasma exposures above that required for antiviral activity for at least some of their dosing interval. Notably, neither chloroquine, hydroxychloroquine nor lopinavir/ritonavir exhibited a sustained plasma concentration above their reported SARS-CoV-2 $\mathrm{EC}_{90}$ across their reported dosing interval. Ultimately, the implications of this for therapy will depend upon whether systemic suppression is a prerequisite for a reduction in morbidity or mortality, but this does raise some concern for ongoing trials with these drugs (chloroquine: NCT04323527; NCT04333628 hydroxychloroquine: NCT04316377; NCT04333225; NCT04307693 and lopinavir/ritonavir: NCT04331834; NCT04255017; NCT04315948). However, the predicted lung accumulation rather than plasma exposure may provide some therapy advantage and/or give more reassurance for ongoing chemoprevention trials.

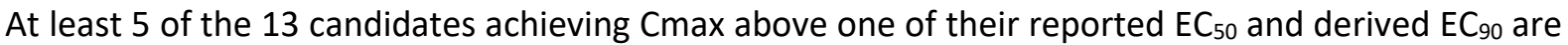
already in clinical evaluation for treatment of SARS-CoV-2. These include remdesivir (NCT04292730; NCT04292899; $\quad$ NCT04257656; $\quad$ NCT04252664; $\quad$ NCT04315948), favipiravir ( NCT04319900), lopinavir/ritonavir and chloroquine. No robust antiviral activity data were found for galidesrivir on which to conduct an analysis but it is also under clinical investigation ( A recent trial for favipirivir, demonstrated some success with an improvement over arbidol from $56 \%$ to $71 \%(p=0.02)$ in patients without risk factors (but not critical cases or patients with hypertension and/or diabetes) [38]. The results of compassionate use of remdesivir in severely ill patients was also recently reported, and if confirmed in ongoing randomized, placebo-controlled trials will serve as a further validation of the other candidates presented here [39]. The authors are unaware of any ongoing COVID-19 trials for the other 7 candidate molecules with $\mathrm{Cmax}$ above their reported $\mathrm{EC}_{90}$, and none were reported on www.clinicaltrials.gov at the time of manuscript submission (14 ${ }^{\text {th }}$ April 2020). 
medRxiv preprint doi: https://doi.org/10.1101/2020.04.16.20068379; this version posted April 22, 2020. The copyright holder for this preprint (which was not certified by peer review) is the author/funder, who has granted medRxiv a license to display the preprint in perpetuity.

All rights reserved. No reuse allowed without permission.

Of particular interest nitazoxanide, tipranavir, sulfadoxine and nelfinavir may be expected to sustain their plasma pharmacokinetic exposure above their lowest reported $\mathrm{EC}_{50}$ and derived $\mathrm{EC}_{90}$ (where available) for the duration of their approved dose and dosing interval.

Nitazoxanide is an antiprotozoal drug that has previously been demonstrated to display broad antiviral activity against human and animal coronaviruses [40] as well as various strains of influenza [41, 42]. Importantly, nitazoxanide is rapidly metabolised to tizoxanide in humans and this active metabolite is

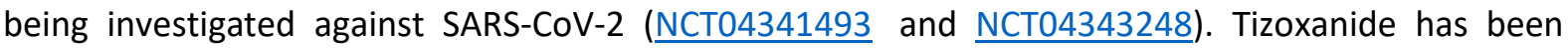
reported to exhibit similar activities to nitazoxanide for other viruses as well as other pathogens [4345]. The mechanism of antiviral action is not fully understood for nitazoxanide, but it has been reported to affect viral genome synthesis, prevent viral entry and interfere with the $\mathrm{N}$-glycosylation and maturation of the influenza hemagglutinin [46-49]. Notably, the SARS-CoV-2 spike protein is also highly $\mathrm{N}$-glycosylated [50]. This drug has also been shown to elicit an innate immune response that potentiates the production of type 1 interferons $[46,51]$ and a phase $2 \mathrm{~b} / 3$ clinical trial demonstrated a reduction in symptoms and viral shedding in patients with uncomplicated influenza [42]. The safety of nitazoxanide is well understood, but it has not been fully investigated during renal or hepatic impairment. The antiviral activity of nitazoxanide for SARS-CoV-2 requires further study but the existing data for this drug are encouraging. Niclosamide is another antiprotozoal drug that exhibits broad antiviral activity due to its ability to perturb the $\mathrm{pH}$-dependent membrane fusion required for virus entry [52] but it was reported to have no impact upon the attachment and entry of SARS-CoV-2 [53]. For MERS-CoV niclosamide was observed to inhibit SKP2 activity impairing viral replication [54]. Niclosamide has been reported to be well tolerated and does not influence vital organ functions [55]. However, it has low aqueous solubility and poor oral bioavailability [56] and despite a higher reported SARS-CoV-2 potency [28] than nitazoxanide [27], the $\mathrm{Cmax} / \mathrm{EC}_{90}$ ratio was slightly lower. There is a paucity of published pharmacokinetic data for niclosamide and this prohibited a thorough investigation of exposures in relation to activity over its entire dosing interval. Both nitazoxanide and niclosamide have also been reported to be potent antagonists of TMEM16A, calcium activated chloride channels that modulate bronchodilation [57].

Tipranavir and nelfinavir are HIV protease inhibitors [58] and both drugs ranked highly in terms of their $\mathrm{Cmax} / \mathrm{EC}_{90}$ ratio. Moreover, a more in-depth analysis demonstrated that the concentrations across the dosing interval for both these drugs remained above the calculated $\mathrm{EC}_{90}$ values at approved doses and schedules. Unlike nelfinavir, tipranavir has to be co-administered with a low dose of ritonavir to boost its pharmacokinetics via CYP3A4 inhibition [59]. Since ritonavir itself has been reported to exert anti-SARS-CoV-2 activity, this could be advantageous, but would need to be balanced against the much higher risk of drug-drug interactions that could negatively impact patient 
medRxiv preprint doi: https://doi.org/10.1101/2020.04.16.20068379; this version posted April 22, 2020. The copyright holder for this preprint (which was not certified by peer review) is the author/funder, who has granted medRxiv a license to display the preprint in perpetuity.

All rights reserved. No reuse allowed without permission.

management. The implications of drug interactions have already been raised for this reason with lopinavir/ritonavir use for COVID-19 [60] and are likely to be exacerbated with the higher ritonavir dose needed for tipranavir. Moreover, tipranavir has a black box warning from the FDA for fatal and nonfatal intracranial haemorrhage as well as severe hepatotoxicity [61-63]. The major route of metabolic clearance for nelfinavir is via CYP2C19 and this pathway generates the M8 metabolite that retains activity against the HIV protease [64]. No data are available for inhibition of SARS-CoV-2 replication by the M8 metabolite but if active, this could provide and advantage for nelfinavir over tipranavir for COVID-19. Conversely, While the analysis of pharmacokinetics relative to potency of these molecules against SARS-CoV-2 is encouraging, it should be noted that the reported in vitro activity for HIV $[58,65]$ is far higher than that against SARS-CoV-2 and both drugs are highly protein bound $[66,67]$. While older HIV protease inhibitors like tipranavir and nelfinavir are associated with long-term toxicities $[58,68-70]$ these may be less of a concern over shorter term exposure if they prove to be successful for COVID-19.

Sulfadoxine is another antimalarial drug that is usually administered in combination with pyrimethamine as a folic acid antagonist combination [71]. Sulfadoxine inhibits the activity of dihydropteroate synthase within the malaria parasite, but its mechanism of action for SARS-CoV-2 is unclear. It should also be noted that the authors can find no data describing antiviral activity of this drug against other viruses. Also, the concentrations used in the in vitro activity used in this analysis [26] were not high enough to reach or calculate an $\mathrm{EC}_{90}$ value. Therefore, like other molecules described in this manuscript in vitro anti-SARS-CoV-2 activity should be repeated. Notwithstanding, sulfadoxine plasma concentrations far above the reported $\mathrm{EC}_{50}$ are maintained in patients receiving a single $1500 \mathrm{mg}$ dose (with $75 \mathrm{mg}$ pyrimethamine) for over 40 days [72]. Compared to some other reported molecules sulfadoxine is not expected to have as high an accumulation in the lungs, but concentrations higher than its $\mathrm{EC}_{50}$ are estimated from the analysis of its lung $\mathrm{KpU}$. Therefore, if the reported antiviral activity is confirmed this drug may offer opportunities for therapy and/or chemoprophylaxis.

Considering that most of the impact of severe disease occurs in the lung and that this tissue may be a key site for transmission, the potential of candidate drugs to accumulate in lung tissue was considered. The analysis of predicted lung $\mathrm{Cmax}_{\mathrm{a}} \mathrm{EC}_{50}$ ratio revealed more candidates expected to exceed the concentrations needed for antiviral activity in this tissue. Hydroxychloroquine, chloroquine, mefloquine, atazanavir (boosted with ritonavir), tipranavir (boosted with ritonavir), ivermectin and lopinavir were all predicted to achieve lung concentrations over 10-fold higher than their reported $\mathrm{EC}_{50}$. All of these drugs were also predicted to exceed their $\mathrm{EC}_{90}$ in lung by at least 3.4-fold (data not shown). The lung prediction was not possible for nelfinavir because insufficient data were available to 
medRxiv preprint doi: https://doi.org/10.1101/2020.04.16.20068379; this version posted April 22, 2020. The copyright holder for this preprint (which was not certified by peer review) is the author/funder, who has granted medRxiv a license to display the preprint in perpetuity.

All rights reserved. No reuse allowed without permission.

calculate $\mathrm{K}_{\mathrm{p}} \mathrm{U}_{\text {lung }}$ but nitozoxanide and sulfadoxine were also predicted to exceed their reported $\mathrm{EC}_{50}$ by 3.1- and 1.5-fold in lung, respectively. Nitazoxanide was predicted to exceed its EC $_{90}$ by 1.4-fold in lung but an $\mathrm{EC}_{90}$ was not calculable from the available data for sulfadoxine.

During inflammation or injury, changes to the vascular microenvironment, could have a profound effect on the ability of these drugs to accumulate in lung cells. Due to the recruitment of neutrophils and leaky endothelial cells [73], the lung inflammatory microenvironment is characterized by increased body temperature, excessive enzymic activity and most importantly, by a low interstitial pH [74]. In the case of chloroquine and hydroxychloroquine, these diprotic weak bases are exquisitely dependent on a pH gradient to drive lysosomal uptake as a mechanism of lung accumulation. It has been demonstrated that cellular chloroquine uptake is diminished one hundred-fold for every $\mathrm{pH}$ unit of external acidification [75]. This situation is likely to deteriorate further on mechanical ventilation, which also induces acidification of the lung tissue, independently of inflammation [76, 77]. Therefore, the benefits of lung accumulation for many of these drugs may be lost during treatment of severe SARS-CoV-2 infection. Conversely, mefloquine is monoprotic and more lipophilic than chloroquine, which may make it much less reliant on the $\mathrm{pH}$ gradient to drive cellular accumulation in lung. It is likely that the charged form of the drug is sufficiently lipophilic to allow movement across biological membranes along a concentration gradient [78]. Only two studies have described mefloquine uptake into cells, one study suggested that mefloquine uptake is not energy-dependent and the other suggested that mefloquine uptake is mediated by secondary active transport, rather than passive proton trapping $[79,80]$. Mefloquine is known to cause severe psychiatric side effects in some patients and so use of this drug should be managed with care [81]. Therefore, mefloquine may offer opportunities for treatment during severe disease that are not available with other drugs currently being tested for COVID-19 therapy. If the high lung exposures are proven empirically for the drugs on this list, then some may also prove to be valuable for chemoprevention strategies.

\section{Limitations of this analysis}

This study represents the first holistic view of drugs with reported activity against SARS-CoV-2 in the context of their achievable pharmacokinetic exposure in humans. While the analysis does provide a basis to rationally selected candidates for further analysis, there are some important limitations. Firstly, Cmax was the only pharmacokinetic parameter that was universally available for all of the candidate drugs, but Cmin values are generally accepted as a better marker of efficacy since they represent the lowest plasma concentration over the dosing interval. However, Cmax was only used to 
medRxiv preprint doi: https://doi.org/10.1101/2020.04.16.20068379; this version posted April 22, 2020. The copyright holder for this preprint (which was not certified by peer review) is the author/funder, who has granted medRxiv a license to display the preprint in perpetuity.

All rights reserved. No reuse allowed without permission.

assess whether plasma concentration would exceed those required at any point in the dosing interval, and this was followed by a more in-depth analysis of the most promising candidates.

Secondly, an $\mathrm{EC}_{50}$ value only equates to a concentration required to suppress $50 \%$ of the virus, and data were unavailable to calculate $\mathrm{EC}_{90}$ values for some of the drugs. $\mathrm{EC}_{90}$ values are a preferred marker of activity because the slope of the concentration-response curve can vary substantially between different molecules and between different mechanisms of action. Although $\mathrm{EC}_{90}$ were not calculable for all drugs the authors deemed it appropriate to deprioritise molecules not achieving $\mathrm{EC}_{50}$ at Cmax in this analysis. Thirdly, the reported antiviral activities were conducted under different conditions (Table 1) and in several cases varied between the same molecule assessed in different studies (Figure 1). No mitigation strategy was possible for this limitation and the data should be interpreted in the context that the quality of the available data may profoundly impact the conclusions. Furthermore in vitro activity should be confirmed for the promising candidates.

Fourthly, plasma protein binding can be an important factor in determining whether sufficient free drug concentration are available to exert antiviral activity [86] and insufficient data were available across the dataset to determine protein binding-adjusted $\mathrm{EC}_{90}$ values. This is important because for highly protein bound drugs the antiviral activity in plasma may be lower than reported in vitro activity because protein concentrations used in culture media are lower than those in plasma. Fifthly, robust pharmacokinetic data were not available for all the molecules and subtle differences have been reported in the pharmacokinetics in different studies. Where possible, this analysis utilised the pharmacokinetics described at the highest doses approved for other indications and checked them to ensure that profound differences were not evident between different studies. However, in some cases higher doses and/or more frequent dosing has been investigated for some of the drugs mentioned so higher exposures may be available for some drugs with off-label dosing. Sixthly, the digitised pharmacokinetic plots presented in this manuscript represent the mean or median profiles depending on what was presented in the original manuscripts. Many of the drugs presented are known to exhibit high inter-individual variability that is not captured within the presented analysis and it is possible that even for promising candidates a significant proportion of patients may have sub-therapeutic concentrations despite population mean/median being higher than the Cmax. Advanced pharmacokinetics modelling approaches will be needed to unpick this and are currently underway by the authors.

Seventhly, the presented predictions for lung accumulation may offer a basis for ranking molecules for expected accumulation in that organ, but ultimate effectiveness of a chemoprophylactic approach will likely depend upon penetration into other critical matrices in the upper airways, for which there 
medRxiv preprint doi: https://doi.org/10.1101/2020.04.16.20068379; this version posted April 22, 2020. The copyright holder for this preprint (which was not certified by peer review) is the author/funder, who has granted medRxiv a license to display the preprint in perpetuity.

All rights reserved. No reuse allowed without permission.

are currently no robustly validated methods of prediction. Also, while a generally accepted method for assessing $\mathrm{KpU}$ was employed, the predictions are not supported by any empirical investigation of the lung accumulation.

Finally, this analysis assumes that drugs need to be active within the systemic compartment in order to have efficacy against SARS-CoV-2. Since current evidence suggests that the virus is widely disseminated throughout the body this is a logical assumption. However, ultimate efficacy of any drug can only be demonstrated with robust clinical trial designs.

\section{Summary}

The current analysis reveals that many putative agents are never likely to achieve target concentrations necessary to adequately suppress SARS-CoV-2 under normal dosing conditions. It is critical that candidate medicines emerging from in vitro antiviral screening programmes are considered in the context of their expected exposure in humans where possible. Clinical trials are extremely time consuming and expensive, and it is critical that only the best options are progressed for robust analysis as potential mono- or combination therapy or prevention options. Finally, it would be highly beneficial for activity data for SARS-CoV-2 to be performed with standardised protocol and with activity reported as $\mathrm{EC}_{90}$ values as a better marker of the concentrations required to suppress the virus to therapeutically relevant levels. 
medRxiv preprint doi: https://doi.org/10.1101/2020.04.16.20068379; this version posted April 22, 2020. The copyright holder for this preprint (which was not certified by peer review) is the author/funder, who has granted medRxiv a license to display the preprint in perpetuity.

\section{References}

1. Gu, J., B. Han, and J. Wang, COVID-19: Gastrointestinal manifestations and potential fecaloral transmission. Gastroenterology, 2020.

2. World Health Organisation, COVID-19 Trials - International Clinical Trials Registry Platform (ICTRP). 2020.

3. Qin, C., et al., Dysregulation of immune response in patients with COVID-19 in Wuhan, China. Clin Infect Dis, 2020.

4. $\quad \mathrm{Li}, \mathrm{W}$., et al., Angiotensin-converting enzyme 2 is a functional receptor for the SARS coronavirus. Nature, 2003. 426(6965): p. 450-454.

5. Zhao, Y., et al., Single-cell RNA expression profiling of ACE2, the receptor of SARS-CoV-2. 2020: p. 2020.01.26.919985.

6. Wu, Y., et al., Prolonged presence of SARS-CoV-2 viral RNA in faecal samples. Lancet Gastroenterol Hepatol, 2020.

7. Diao, B., et al., Human Kidney is a Target for Novel Severe Acute Respiratory Syndrome Coronavirus 2 (SARS-CoV-2) Infection. 2020: p. 2020.03.04.20031120.

8. Zhang, C., L. Shi, and F.S. Wang, Liver injury in COVID-19: management and challenges. Lancet Gastroenterol Hepatol, 2020.

9. Guo, Y.R., et al., The origin, transmission and clinical therapies on coronavirus disease 2019 (COVID-19) outbreak - an update on the status. Mil Med Res, 2020. 7(1): p. 11.

10. Hoffmann, M., et al., SARS-CoV-2 Cell Entry Depends on ACE2 and TMPRSS2 and Is Blocked by a Clinically Proven Protease Inhibitor. Cell, 2020.

11. Zhang, H., et al., The digestive system is a potential route of 2019-nCov infection: a bioinformatics analysis based on single-cell transcriptomes. 2020: p. 2020.01.30.927806.

12. Wong, S.H., R.N. Lui, and J.J. Sung, Covid-19 and the Digestive System. J Gastroenterol Hepatol, 2020.

13. Zhang, W., et al., Molecular and serological investigation of 2019-nCoV infected patients: implication of multiple shedding routes. Emerg Microbes Infect, 2020. 9(1): p. 386-389.

14. Sun, C.-b., et al., Role of the Eye in Transmitting Human Coronavirus: What We Know and What We Do Not Know. 2020.

15. Lu, C.W., X.F. Liu, and Z.F. Jia, 2019-nCoV transmission through the ocular surface must not be ignored. Lancet, 2020. 395(10224): p. e39.

16. Smith, C.A., et al., Influenza virus inoculum volume is critical to elucidate age-dependent mortality in mice. Aging Cell, 2019. 18(2): p. e12893.

17. Miller, D.S., T. Kok, and P. Li, The virus inoculum volume influences outcome of influenza $A$ infection in mice. Lab Anim, 2013. 47(1): p. 74-7.

18. Chen, X., et al., Detectable serum SARS-CoV-2 viral load (RNAaemia) is closely associated with drastically elevated interleukin 6 (IL-6) level in critically ill COVID-19 patients. 2020: $\mathrm{p}$. 2020.02.29.20029520.

19. Liu, Y., et al., Viral dynamics in mild and severe cases of COVID-19. Lancet Infect Dis, 2020.

20. Rodgers, T., D. Leahy, and M. Rowland, Physiologically based pharmacokinetic modelling 1: predicting the tissue distribution of moderate-to-strong bases. J Pharm Sci, 2005. 94(6): p. 1259-76.

21. Rodgers, T. and M. Rowland, Physiologically based pharmacokinetic modelling 2: predicting the tissue distribution of acids, very weak bases, neutrals and zwitterions. J Pharm Sci, 2006. 95(6): p. 1238-57.

22. Rodgers, T. and M. Rowland, Mechanistic approaches to volume of distribution predictions: understanding the processes. Pharm Res, 2007. 24(5): p. 918-33.

23. Weston, S., et al., FDA approved drugs with broad anti-coronaviral activity inhibit SARS-CoV$2<$ <em>in vitro</em>. 2020: p. 2020.03.25.008482. 
medRxiv preprint doi: https://doi.org/10.1101/2020.04.16.20068379; this version posted April 22, 2020. The copyright holder for this preprint (which was not certified by peer review) is the author/funder, who has granted medRxiv a license to display the preprint in perpetuity.

All rights reserved. No reuse allowed without permission.

24. Ge, Y., et al., A data-driven drug repositioning framework discovered a potential therapeutic agent targeting COVID-19. 2020: p. 2020.03.11.986836.

25. Bojkova, D., et al., SARS-CoV-2 and SARS-CoV differ in their cell tropism and drug sensitivity profiles. 2020: p. 2020.04.03.024257.

26. Touret, F., et al., In vitro screening of a FDA approved chemical library reveals potential inhibitors of SARS-CoV-2 replication. 2020: p. 2020.04.03.023846.

27. Wang, M., et al., Remdesivir and chloroquine effectively inhibit the recently emerged novel coronavirus (2019-nCoV) in vitro. Cell Res, 2020. 30(3): p. 269-271.

28. Jeon, S., et al., Identification of antiviral drug candidates against SARS-CoV-2 from FDAapproved drugs. 2020: p. 2020.03.20.999730.

29. $\mathrm{Xu}, \mathrm{T}$., et al., Indomethacin has a potent antiviral activity against SARS CoV-2 in vitro and canine coronavirus in vivo. 2020: p. 2020.04.01.017624.

30. Fintelman-Rodrigues, N., et al., Atazanavir inhibits SARS-CoV-2 replication and proinflammatory cytokine production. 2020: p. 2020.04.04.020925.

31. Yamamoto, N., et al., Nelfinavir inhibits replication of severe acute respiratory syndrome coronavirus 2 in vitro. 2020: p. 2020.04.06.026476.

32. Bukreyeva, N., et al., The IMPDH inhibitor merimepodib suppresses SARS-CoV-2 replication <em>in vitro</em>. 2020: p. 2020.04.07.028589.

33. Jin, Z., et al., Structure of Mpro from COVID-19 virus and discovery of its inhibitors. Nature, 2020.

34. Yao, X., et al., In Vitro Antiviral Activity and Projection of Optimized Dosing Design of Hydroxychloroquine for the Treatment of Severe Acute Respiratory Syndrome Coronavirus 2 (SARS-CoV-2). Clin Infect Dis, 2020.

35. Choy, K.-T., et al., Remdesivir, lopinavir, emetine, and homoharringtonine inhibit SARS-CoV-2 replication in vitro. Antiviral Research, 2020. 178: p. 104786.

36. Caly, L., et al., The FDA-approved Drug Ivermectin inhibits the replication of SARS-CoV-2 in vitro. Antiviral Research, 2020: p. 104787.

37. Zhijian, X., et al., Nelfinavir Is Active Against SARS-CoV-2 in Vero E6 Cells. 2020.

38. Chen, C., et al., Favipiravir versus Arbidol for COVID-19: A Randomized Clinical Trial. 2020: p. 2020.03.17.20037432.

39. Grein, J., et al., Compassionate Use of Remdesivir for Patients with Severe Covid-19. 2020.

40. Rossignol, J.F., Nitazoxanide, a new drug candidate for the treatment of Middle East respiratory syndrome coronavirus. J Infect Public Health, 2016. 9(3): p. 227-30.

41. Tilmanis, D., et al., The susceptibility of circulating human influenza viruses to tizoxanide, the active metabolite of nitazoxanide. Antiviral Res, 2017. 147: p. 142-148.

42. Haffizulla, J., et al., Effect of nitazoxanide in adults and adolescents with acute uncomplicated influenza: a double-blind, randomised, placebo-controlled, phase $2 b / 3$ trial. Lancet Infect Dis, 2014. 14(7): p. 609-18.

43. Gekonge, B., M.C. Bardin, and L.J. Montaner, Short communication: Nitazoxanide inhibits HIV viral replication in monocyte-derived macrophages. AIDS Res Hum Retroviruses, 2015. 31(2): p. 237-41.

44. Tilmanis, D., et al., The susceptibility of circulating human influenza viruses to tizoxanide, the active metabolite of nitazoxanide. Antiviral Research, 2017. 147: p. 142-148.

45. Trabattoni, D., et al., Thiazolides Elicit Anti-Viral Innate Immunity and Reduce HIV Replication. Scientific Reports, 2016. 6(1): p. 27148.

46. Rossignol, J.F., Nitazoxanide: a first-in-class broad-spectrum antiviral agent. Antiviral Res, 2014. 110: p. 94-103.

47. Rossignol, J.F., et al., Thiazolides, a new class of anti-influenza molecules targeting viral hemagglutinin at the post-translational level. J Biol Chem, 2009. 284(43): p. 29798-808.

48. Hickson, S.E., et al., Inhibition of vaccinia virus replication by nitazoxanide. Virology, 2018. 518: p. 398-405. 
medRxiv preprint doi: https://doi.org/10.1101/2020.04.16.20068379; this version posted April 22, 2020. The copyright holder for this preprint (which was not certified by peer review) is the author/funder, who has granted medRxiv a license to display the preprint in perpetuity.

All rights reserved. No reuse allowed without permission.

49. Wang, Y.M., et al., Antiviral activities of niclosamide and nitazoxanide against chikungunya virus entry and transmission. Antiviral Res, 2016. 135: p. 81-90.

50. Zhang, Y., et al., Site-specific N-glycosylation Characterization of Recombinant SARS-CoV-2 Spike Proteins using High-Resolution Mass Spectrometry. 2020: p. 2020.03.28.013276.

51. Clerici, M., et al., The anti-infective Nitazoxanide shows strong immumodulating effects (155.21). 2011. 186(1 Supplement): p. 155.21-155.21.

52. Jurgeit, A., et al., Niclosamide is a proton carrier and targets acidic endosomes with broad antiviral effects. PLoS Pathog, 2012. 8(10): p. e1002976.

53. Zhang, X.W. and Y.L. Yap, Old drugs as lead compounds for a new disease? Binding analysis of SARS coronavirus main proteinase with HIV, psychotic and parasite drugs. Bioorg Med Chem, 2004. 12(10): p. 2517-21.

54. Gassen, N.C., et al., SKP2 attenuates autophagy through Beclin1-ubiquitination and its inhibition reduces MERS-Coronavirus infection. Nat Commun, 2019. 10(1): p. 5770.

55. Li, R., et al., Inhibition of STAT3 by niclosamide synergizes with erlotinib against head and neck cancer. PLoS One, 2013. 8(9): p. e74670.

56. Lin, C.K., et al., Preclinical evaluation of a nanoformulated antihelminthic, niclosamide, in ovarian cancer. Oncotarget, 2016. 7(8): p. 8993-9006.

57. Miner, K., et al., Drug Repurposing: The Anthelmintics Niclosamide and Nitazoxanide Are Potent TMEM16A Antagonists That Fully Bronchodilate Airways. Front Pharmacol, 2019. 10: p. 51.

58. Lv, Z., Y. Chu, and Y. Wang, HIV protease inhibitors: a review of molecular selectivity and toxicity. HIV AIDS (Auckl), 2015. 7: p. 95-104.

59. Streeck, H. and J.K. Rockstroh, Review of tipranavir in the treatment of drug-resistant HIV. Ther Clin Risk Manag, 2007. 3(4): p. 641-51.

60. Sanders, J.M., et al., Pharmacologic Treatments for Coronavirus Disease 2019 (COVID-19): A Review. JAMA, 2020.

61. Justice, A.C., et al., Drug Toxicity, HIV Progression, or Comorbidity of Aging: Does Tipranavir Use Increase the Risk of Intracranial Hemorrhage? Clinical Infectious Diseases, 2008. 47(9): p. 1226-1230.

62. Flexner, C., G. Bate, and P. Kirkpatrick, Tipranavir. Nature Reviews Drug Discovery, 2005. 4(12): p. 955-956.

63. Chan-Tack, K.M., K.A. Struble, and D.B. Birnkrant, Intracranial hemorrhage and liverassociated deaths associated with tipranavir/ritonavir: review of cases from the FDA's Adverse Event Reporting System. AIDS Patient Care STDS, 2008. 22(11): p. 843-50.

64. Hirani, V.N., J.L. Raucy, and J.M. Lasker, Conversion of the HIV protease inhibitor nelfinavir to a bioactive metabolite by human liver CYP2C19. Drug Metab Dispos, 2004. 32(12): p. 1462-7.

65. Zhang, K.E., et al., Circulating metabolites of the human immunodeficiency virus protease inhibitor nelfinavir in humans: structural identification, levels in plasma, and antiviral activities. Antimicrob Agents Chemother, 2001. 45(4): p. 1086-93.

66. Motoya, T., et al., Characterization of nelfinavir binding to plasma proteins and the lack of drug displacement interactions. HIV Med, 2006. 7(2): p. 122-8.

67. King, J.R. and E.P. Acosta, Tipranavir. Clinical Pharmacokinetics, 2006. 45(7): p. 665-682.

68. Markowitz, M., et al., Long-term efficacy and safety of tipranavir boosted with ritonavir in HIV-1-infected patients failing multiple protease inhibitor regimens: 80 -week data from a phase 2 study. J Acquir Immune Defic Syndr, 2007. 45(4): p. 401-10.

69. Justice, A.C., et al., Drug toxicity, HIV progression, or comorbidity of aging: does tipranavir use increase the risk of intracranial hemorrhage? Clin Infect Dis, 2008. 47(9): p. 1226-30.

70. Unis, G., et al., Mitochondrial Mechanisms of Nelfinavir Toxicity in Human Brain Microvascular Endothelial cells. 2016. 30(1_supplement): p. 953.4-953.4. 
medRxiv preprint doi: https://doi.org/10.1101/2020.04.16.20068379; this version posted April 22, 2020. The copyright holder for this preprint (which was not certified by peer review) is the author/funder, who has granted medRxiv a license to display the preprint in perpetuity.

All rights reserved. No reuse allowed without permission.

71. Lovegrove, F.E. and K.C. Kain, Chapter 6 - Malaria Prevention, in The Travel and Tropical Medicine Manual (Fourth Edition), E.C. Jong and C. Sanford, Editors. 2008, W.B. Saunders: Edinburgh. p. 76-99.

72. de Kock, M., et al., Pharmacokinetics of Sulfadoxine and Pyrimethamine for Intermittent Preventive Treatment of Malaria During Pregnancy and After Delivery. CPT Pharmacometrics Syst Pharmacol, 2017. 6(7): p. 430-438.

73. Pober, J.S. and W.C. Sessa, Evolving functions of endothelial cells in inflammation. Nat Rev Immunol, 2007. 7(10): p. 803-15.

74. Zhang, R., et al., Tumor-associated inflammatory microenvironment in non-small cell lung cancer: correlation with FGFR1 and TLR4 expression via PI3K/Akt pathway. J Cancer, 2019. 10(4): p. 1004-1012.

75. Geary, T.G., et al., Kinetic modelling of the response of Plasmodium falciparum to chloroquine and its experimental testing in vitro. Implications for mechanism of action of and resistance to the drug. Biochem Pharmacol, 1990. 40(4): p. 685-91.

76. Pugin, J., et al., Cyclic stretch of human lung cells induces an acidification and promotes bacterial growth. Am J Respir Cell Mol Biol, 2008. 38(3): p. 362-70.

77. Drachman, N., et al., In vivo pH mapping of injured lungs using hyperpolarized [1-(13) C]pyruvate. Magn Reson Med, 2017. 78(3): p. 1121-1130.

78. Ginsburg, H., E. Nissani, and M. Krugliak, Alkalinization of the food vacuole of malaria parasites by quinoline drugs and alkylamines is not correlated with their antimalarial activity. Biochem Pharmacol, 1989. 38(16): p. 2645-54.

79. Vanderkooi, G., P. Prapunwattana, and Y. Yuthavong, Evidence for electrogenic accumulation of mefloquine by malarial parasites. Biochem Pharmacol, 1988. 37(19): p. 3623-31.

80. Fitch, C.D., R. Chevli, and Y. Gonzalez, Chloroquine-resistant Plasmodium falciparum: effect of substrate on chloroquine and amodiaquin accumulation. Antimicrob Agents Chemother, 1974. 6(6): p. 757-62.

81. Ritchie, E.C., J. Block, and R.L. Nevin, Psychiatric side effects of mefloquine: applications to forensic psychiatry. J Am Acad Psychiatry Law, 2013. 41(2): p. 224-35.

82. Hamaguchi, M., et al., Successful treatment of non-HIV progressive multifocal leukoencephalopathy: case report and literature review. J Neurol, 2020. 267(3): p. 731-738.

83. Pham, Y.T., et al., Cerebral uptake of mefloquine enantiomers in fatal cerebral malaria. International journal of clinical pharmacology and therapeutics, 1999. 37(1): p. 58-61.

84. Baig, A.M., et al., Evidence of the COVID-19 Virus Targeting the CNS: Tissue Distribution, Host-Virus Interaction, and Proposed Neurotropic Mechanisms. ACS Chem Neurosci, 2020. 11(7): p. 995-998.

85. Wu, Y., et al., Nervous system involvement after infection with COVID-19 and other coronaviruses. Brain, Behavior, and Immunity, 2020.

86. Gonzalez, D., S. Schmidt, and H. Derendorf, Importance of relating efficacy measures to unbound drug concentrations for anti-infective agents. Clin Microbiol Rev, 2013. 26(2): p. 274-88.

87. Fox, L.M. and L.D. Saravolatz, Nitazoxanide: A New Thiazolide Antiparasitic Agent. Clinical Infectious Diseases, 2005. 40(8): p. 1173-1180.

88. la Porte, C.J., et al., Lack of effect of efavirenz on the pharmacokinetics of tipranavir-ritonavir in healthy volunteers. Antimicrob Agents Chemother, 2009. 53(11): p. 4840-4.

89. Kruse, G., et al., The steady-state pharmacokinetics of nelfinavir in combination with tenofovir in HIV-infected patients. Antivir Ther, 2005. 10(2): p. 349-55.

90. Rainsford, K.D., et al., Effects of misoprostol on the pharmacokinetics of indomethacin in human volunteers. Clin Pharmacol Ther, 1992. 51(4): p. 415-21.

91. Burger, D.M., et al., Effect of Rifampin on Steady-State Pharmacokinetics of Atazanavir with Ritonavir in Healthy Volunteers. 2006. 50(10): p. 3336-3342. 
medRxiv preprint doi: https://doi.org/10.1101/2020.04.16.20068379; this version posted April 22, 2020. The copyright holder for this preprint (which was not certified by peer review) is the author/funder, who has granted medRxiv a license to display the preprint in perpetuity.

All rights reserved. No reuse allowed without permission.

92. Tett, S.E., et al., Concentration-effect relationship of hydroxychloroquine in patients with rheumatoid arthritis--a prospective, dose ranging study. J Rheumatol, 2000. 27(7): p. 165660.

93. Shida, Y., et al., Pharmacokinetics and Pharmacodynamics of Eltrombopag in Healthy Japanese Males. Rinsho yakuri/Japanese Journal of Clinical Pharmacology and Therapeutics, 2011. 42(1): p. 11-20.

94. FDA. Abbott L. Clinical Pharmacology and Biopharmaceutics review of Kaletra oral solution (NDA\#021251). 2020 [cited 2020 13/04]; Available from: https://www.accessdata.fda.gov/drugsatfda docs/nda/2000/21226 Kaletra biopharmr P1.pdf.

95. Na-Bangchang, K., et al., The pharmacokinetics of chloroquine in healthy Thai subjects and patients with Plasmodium vivax malaria. Br J Clin Pharmacol, 1994. 38(3): p. 278-81.

96. Krudsood, S., et al., New Fixed-Dose Artesunate-Mefloquine Formulation against MultidrugResistant <em>Plasmodium falciparum</em> in Adults: a Comparative Phase Ilb Safety and Pharmacokinetic Study with Standard-Dose Nonfixed Artesunate plus Mefloquine. 2010. 54(9): p. 3730-3737.

97. Liu, P., et al., Pharmacokinetics of anidulafungin in critically ill patients with candidemia/invasive candidiasis. Antimicrob Agents Chemother, 2013. 57(4): p. 1672-6.

98. Fintelman-Rodrigues, N., et al., Atazanavir inhibits SARS-CoV-2 replication and proinflammatory cytokine production. 2020: p. 2020.04.04.020925.

99. Raja, A., J. Lebbos, and P. Kirkpatrick, Atazanavir sulphate. Nature Reviews Drug Discovery, 2003. 2(11): p. 857-858.

100. Harrison, T.S. and L.J. Scott, Atazanavir. Drugs, 2005. 65(16): p. 2309-2336.

101. Murdoch, D. and G.L. Plosker, Anidulafungin. Drugs, 2004. 64(19): p. 2249-2258.

102. Goel, P. and V. Gerriets, Chloroquine, in StatPearls. 2020: Treasure Island (FL).

103. Garnock-Jones, K.P., Eltrombopag. Drugs, 2011. 71(10): p. 1333-1353.

104. PMDA. Report on the Deliberation Results 2014 Available from: https://www.pmda.go.jp/files/000210319.pdf.

105. Ben-Zvi, I., et al., Hydroxychloroquine: from malaria to autoimmunity. Clin Rev Allergy Immunol, 2012. 42(2): p. 145-53.

106. Yeh, K.C., Pharmacokinetic overview of indomethacin and sustained-release indomethacin. Am J Med, 1985. 79(4C): p. 3-12.

107. Corbett, A.H., M.L. Lim, and A.D. Kashuba, Kaletra (lopinavir/ritonavir). Ann Pharmacother, 2002. 36(7-8): p. 1193-203.

108. Price, R.N., et al., Artesunate/mefloquine treatment of multi-drug resistant falciparum malaria. Trans R Soc Trop Med Hyg, 1997. 91(5): p. 574-7.

109. McHutchison, J.G., et al., A randomized, double-blind, placebo-controlled dose-escalation trial of merimepodib (VX-497) and interferon-alpha in previously untreated patients with chronic hepatitis C. Antivir Ther, 2005. 10(5): p. 635-43.

110. James, J.S., Nelfinavir (Viracept) approved: fourth protease inhibitor available. AIDS Treat News, 1997(No 267): p. 1-2.

111. Chen, W., et al., Niclosamide: Beyond an antihelminthic drug. Cellular Signalling, 2018. 41: p. 89-96.

112. Anderson, V.R. and M.P. Curran, Nitazoxanide. Drugs, 2007. 67(13): p. 1947-1967.

113. Porche, D.J., Ritonavir (Norvir). J Assoc Nurses AIDS Care, 1997. 8(6): p. 81-3.

114. Miller, K.D., et al., Severe cutaneous reactions among American travelers using pyrimethamine-sulfadoxine (Fansidar) for malaria prophylaxis. Am J Trop Med Hyg, 1986. 35(3): p. 451-8.

115. Orman, J.S. and C.M. Perry, Tipranavir: a review of its use in the management of HIV infection. Drugs, 2008. 68(10): p. 1435-63. 
medRxiv preprint doi: https://doi.org/10.1101/2020.04.16.20068379; this version posted April 22, 2020. The copyright holder for this preprint (which was not certified by peer review) is the author/funder, who has granted medRxiv a license to display the preprint in perpetuity.

All rights reserved. No reuse allowed without permission.

\section{Figure legends}

Figure 1. Assessment of the variation in reported $E_{50}$ values for SARS-CoV-2 across the drugs for which more than one value was available in the literature (A). The consequences of this variability in reported $\mathrm{EC}_{50}$ in terms of the $\mathrm{Cmax} / \mathrm{EC}_{50}$ ratio is also provided (B). Amodiaquine and toremifene were estimated to exhibit sub-therapeutic pharmacokinetics irrespective of which $\mathrm{EC}_{50}$ value was used. Similarly, nelfinavir was estimated to have $\mathrm{Cmax}$ value higher than its $\mathrm{EC}_{50}$ irrespective of which $\mathrm{EC}_{50}$ was used in the analysis. For the other drugs, interpretation was highly dependent upon which reported $\mathrm{EC}_{50}$ was utilised and this underscores the caution that should be taken in interpreting the available data.

Figure 2. A bar chart displaying $\mathrm{Cmax}_{\operatorname{ma}} \mathrm{EC}_{90}$ ratio for compounds studied for in vitro antiviral activity against SARS-CoV-2 for which data were available to recalculate an $\mathrm{EC}_{90}$. Drugs with a ratio below 1 were deemed not to provide plasma concentrations at their approved doses to exert sufficient systemic antiviral activity. Those drugs with a ratio above 1 (shown in orange) were deemed to have potential to provide plasma concentrations sufficient to exert at least some antiviral activity for at least some of their dosing interval at their approved dose. Drugs shown in green were predicted to exceed plasma concentrations over their $\mathrm{EC}_{90}$ by more than a two-fold.

Figure 3. Digitised pharmacokinetic interrogation of all drugs calculated to have a $\mathrm{Cmax} / \mathrm{EC}_{50}$ ratio above 1. The lowest reported SARS-CoV-2 $\mathrm{EC}_{50}$ (dashed orange lines) and associated recalculated $\mathrm{EC}_{90}$ (dashed green lines) are also highlighted. References for the utilised data are nitazoxanide 500mg BID and $1000 \mathrm{mg}$ BID [87], tipranavir 500mg BID with $200 \mathrm{mg}$ ritonavir [88], sulfadoxine $1500 \mathrm{mg}$ with $75 \mathrm{mg}$ pyrimethamine [72], nelfinavir 1250mg BID [89], indomethacin 50mg TID [90], atazanavir 300mg QD with 100mg ritonavir [91], hydroxychloroquine $2000 \mathrm{mg}$ hydroxychloroquine sulfate / $1550 \mathrm{mg}$ base administered over 3 days [92], Eltrombobag 75mg single dose [93], lopinavir $400 \mathrm{mg}$ with $100 \mathrm{mg}$ ritonavir [94], chloroquine $1500 \mathrm{mg}$ administered over 3 days [95], mefloquine 1200mg over 3 days [96], anidulafungin $100 \mathrm{mg}$ QD [97]. Robust pharmacokinetic data were unavailable for niclosamide $500 \mathrm{mg}$, ritonavir $600 \mathrm{mg}$ and merimepodib $300 \mathrm{mg}$ in order to conduct this digitised interrogation of these molecules.

Figure 4. A bar chart displaying the simulated lung $\mathrm{Cmax}_{\mathrm{a}} \mathrm{EC} \mathrm{C}_{50}$. Drugs with a ratio below 1 were deemed not to provide lung concentrations at their approved doses to exert sufficient pulmonary antiviral activity for treatment or prevention strategies. Those drugs with a ratio above 1 (shown in orange) were estimated to provide lung concentrations sufficient to exert at least some antiviral activity at their approved dose. Drugs shown in green were predicted to exceed lung concentrations over their $\mathrm{EC}_{50}$ by more than a ten-fold. 
medRxiv preprint doi: https://doi.org/10.1101/2020.04.16.20068379; this version posted April 22, 2020. The copyright holder for this preprint (which was not certified by peer review) is the author/funder, who has granted medRxiv a license to display the preprint in perpetuity.

All rights reserved. No reuse allowed without permission.

\section{Figures}

Figure 1

A)

\section{0}

$\vec{\xi} 25000$

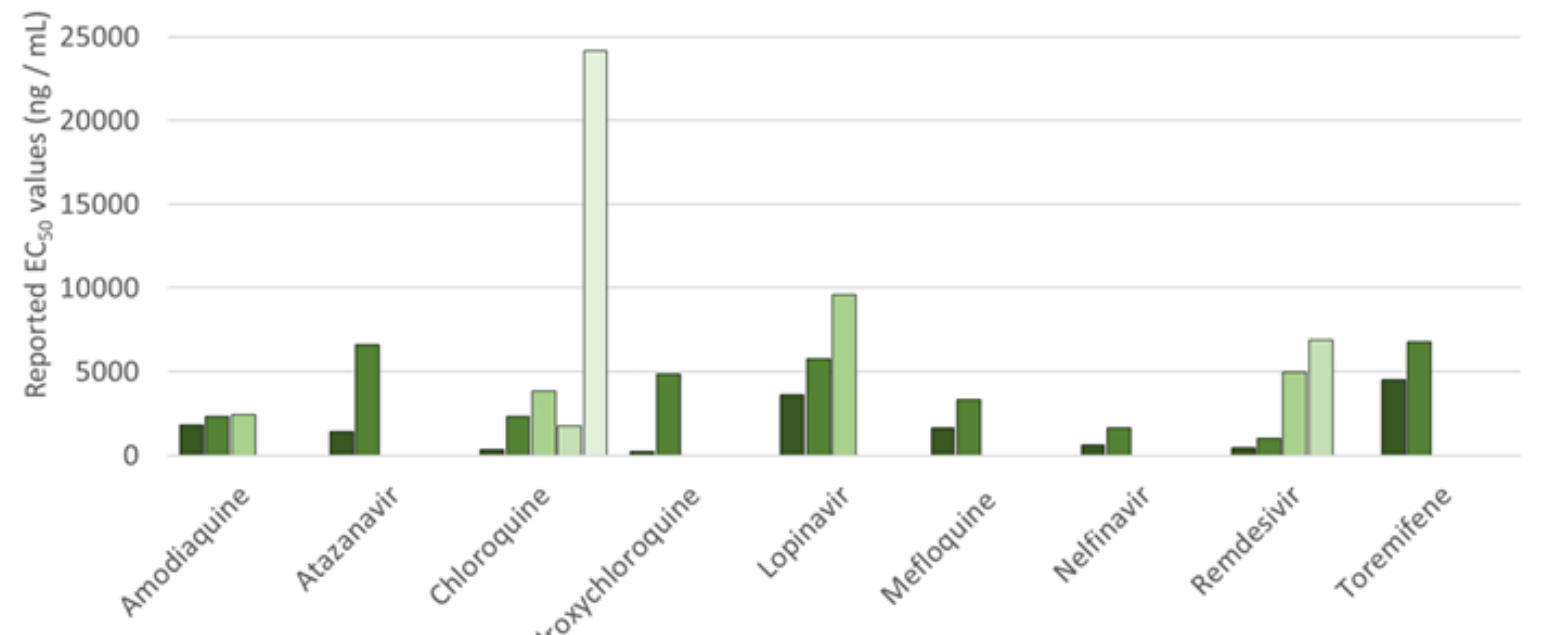

B)

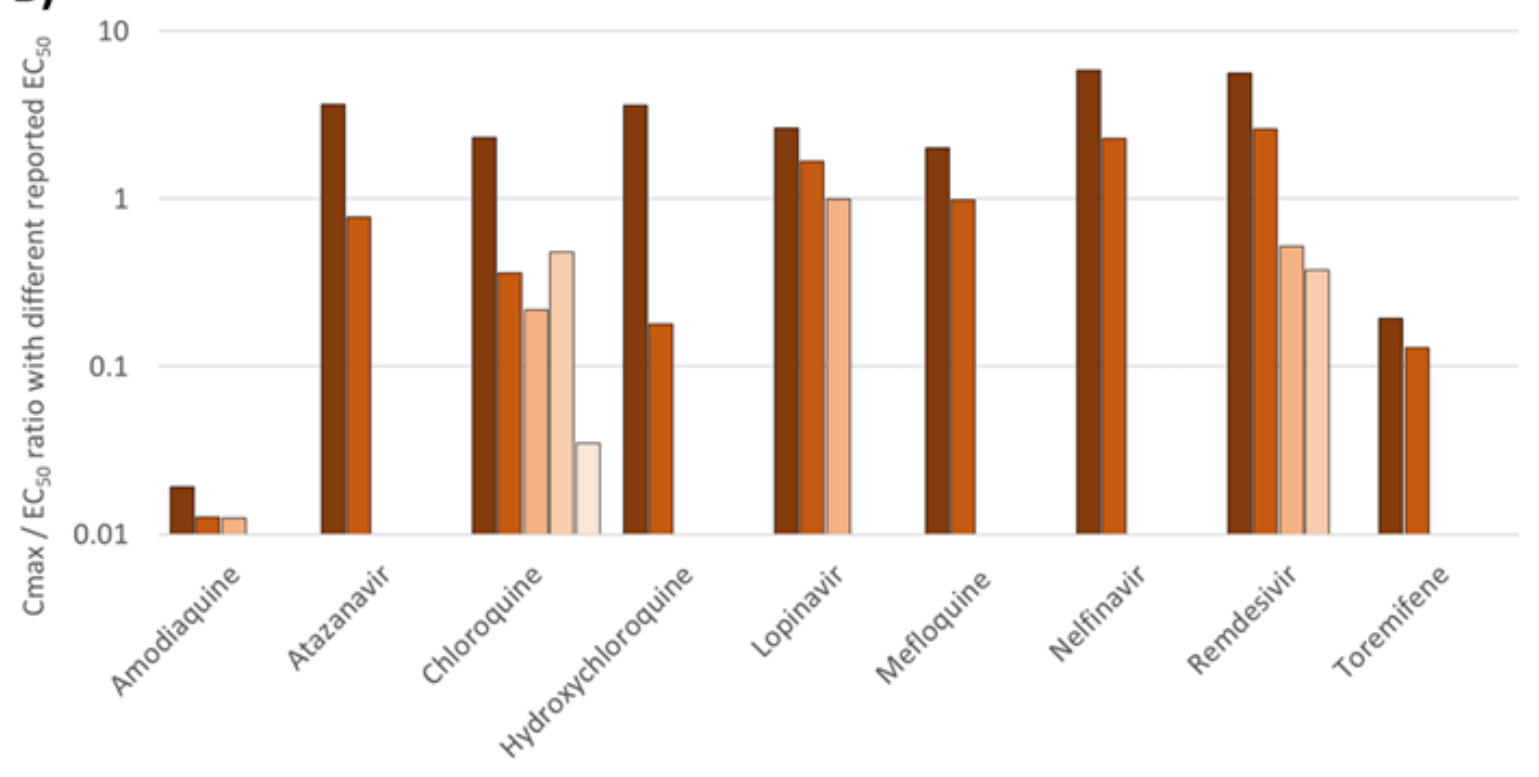


medRxiv preprint doi: https://doi.org/10.1101/2020.04.16.20068379; this version posted April 22, 2020. The copyright holder for this preprint (which was not certified by peer review) is the author/funder, who has granted medRxiv a license to display the preprint in perpetuity.

All rights reserved. No reuse allowed without permission.

\section{Figure 2}

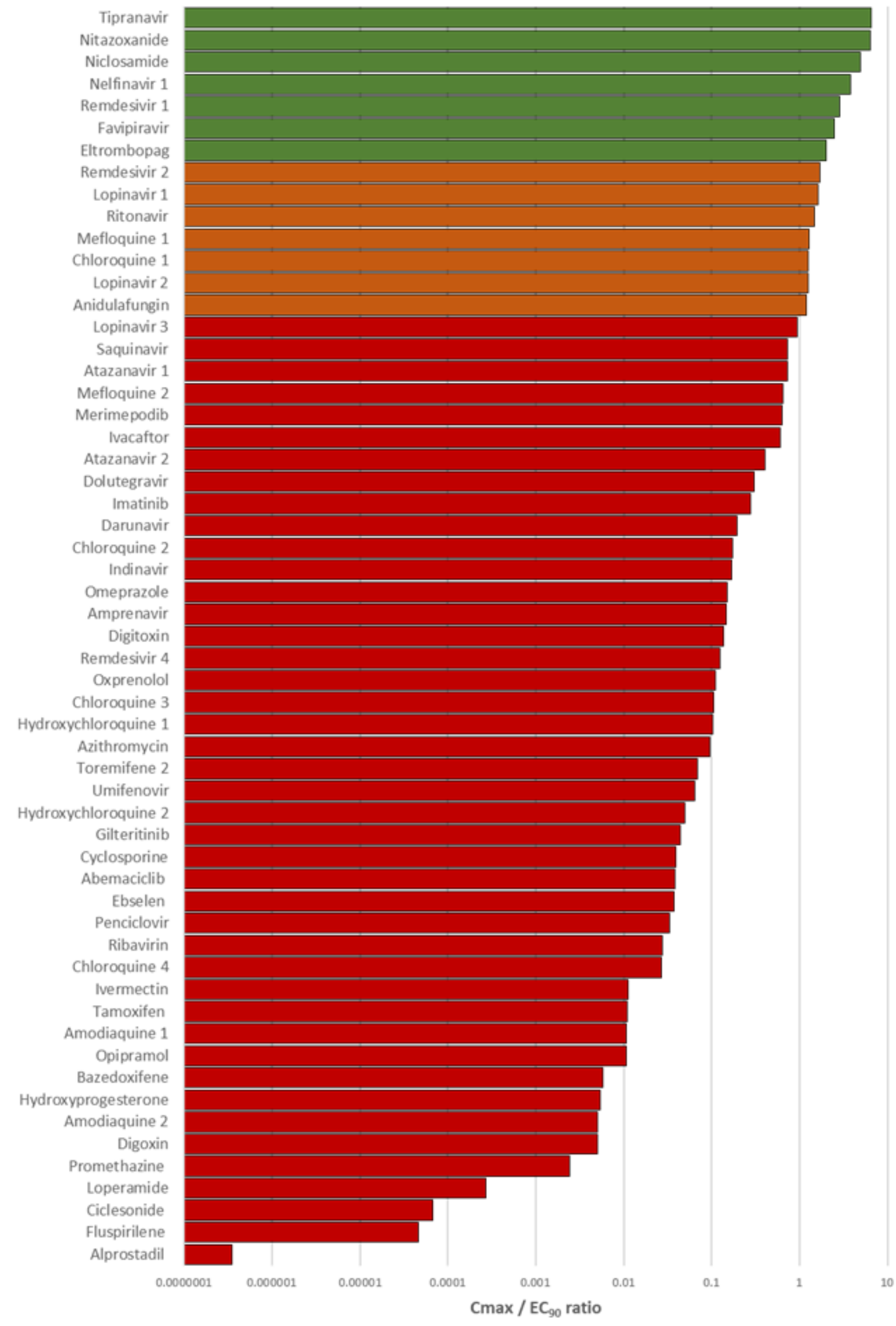


medRxiv preprint doi: https://doi.org/10.1101/2020.04.16.20068379; this version posted April 22, 2020. The copyright holder for this preprint (which was not certified by peer review) is the author/funder, who has granted medRxiv a license to display the preprint in perpetuity.

All rights reserved. No reuse allowed without permission.

\section{Figure 3}
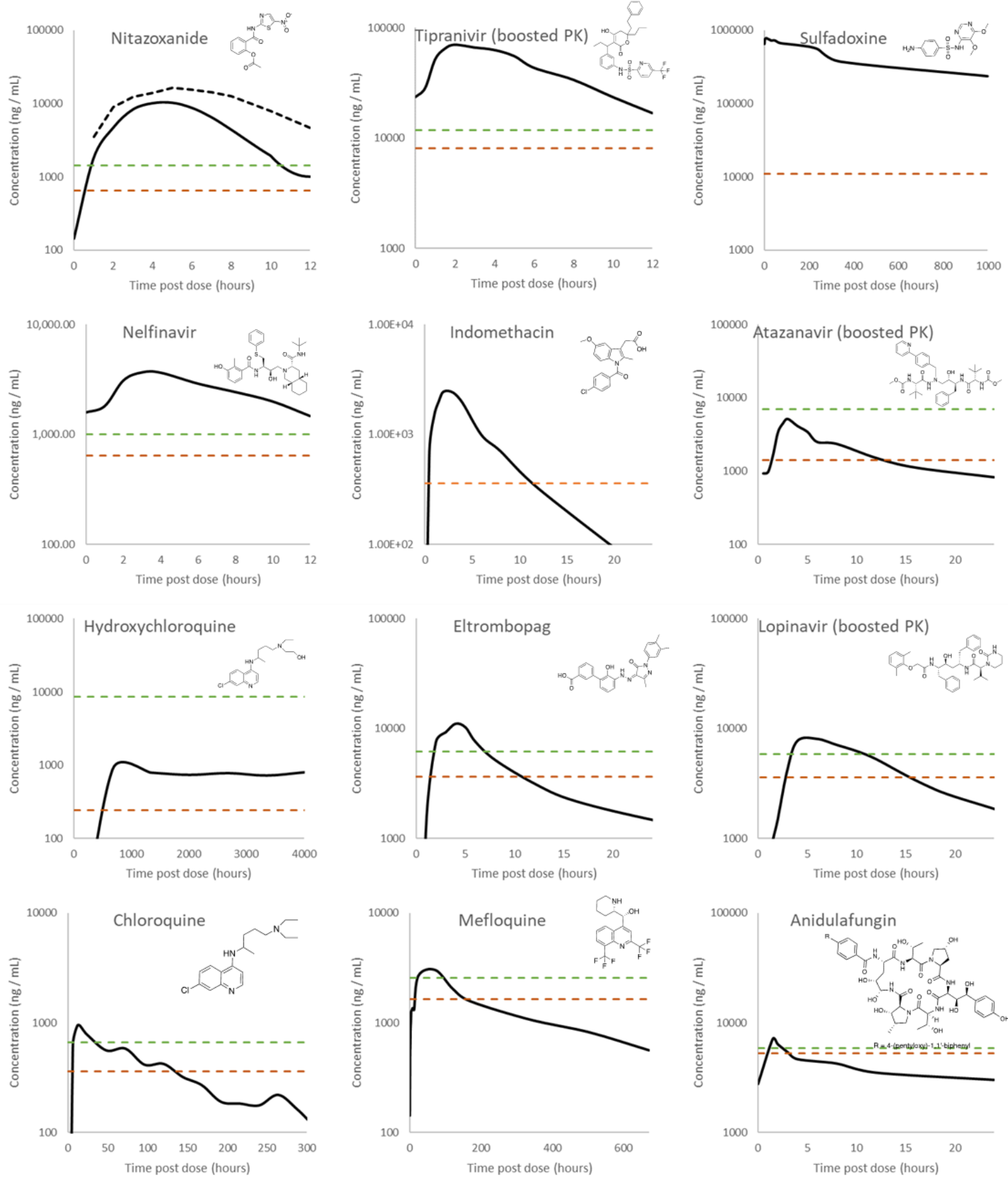
medRxiv preprint doi: https://doi.org/10.1101/2020.04.16.20068379; this version posted April 22, 2020. The copyright holder for this preprint

(which was not certified by peer review) is the author/funder, who has granted medRxiv a license to display the preprint in perpetuity.

All rights reserved. No reuse allowed without permission.

\section{Figure 4}

Hydroxychloroquine 1

Atazanavir 1

Chloroquine 1

Atazanavir 2

Tipranavir

Chloroquine 4

Hydroxychloroquine 2

Chloroquine 2

Chloroquine 3

Mefloquine 1

Ivermectin

Azithromycin

Mefloquine 2

Lopinavir 1

Lopinavir 2

Gilteritinib

Chloroquine 5

Lopinavir 3

Ritonavir

Nitazoxanide

Imatinib

Oxprenolo

Favipiravir

Sulfadoxine

Indomethacin

Abemaciclib

Anidulafungin

Eltrombopag

Tamoxifen

Hydroxyprogesterone

Clomipramine

Amprenavir

Promethazine

Ivacaftor

Amodiaquine 1

Cyclosporine

Opipramo

Chlorpromazine

Omeprazole

Amodiaquine 2

Amodiaquine 3

Dolutegravir

Darunavir

Baricitinib

Penciclovir

Ribavirin

Digitoxin

Bazedoxifene

Homoharringtonine

Digoxin

Ciclesonide

Fluphenazine

Alprostadil

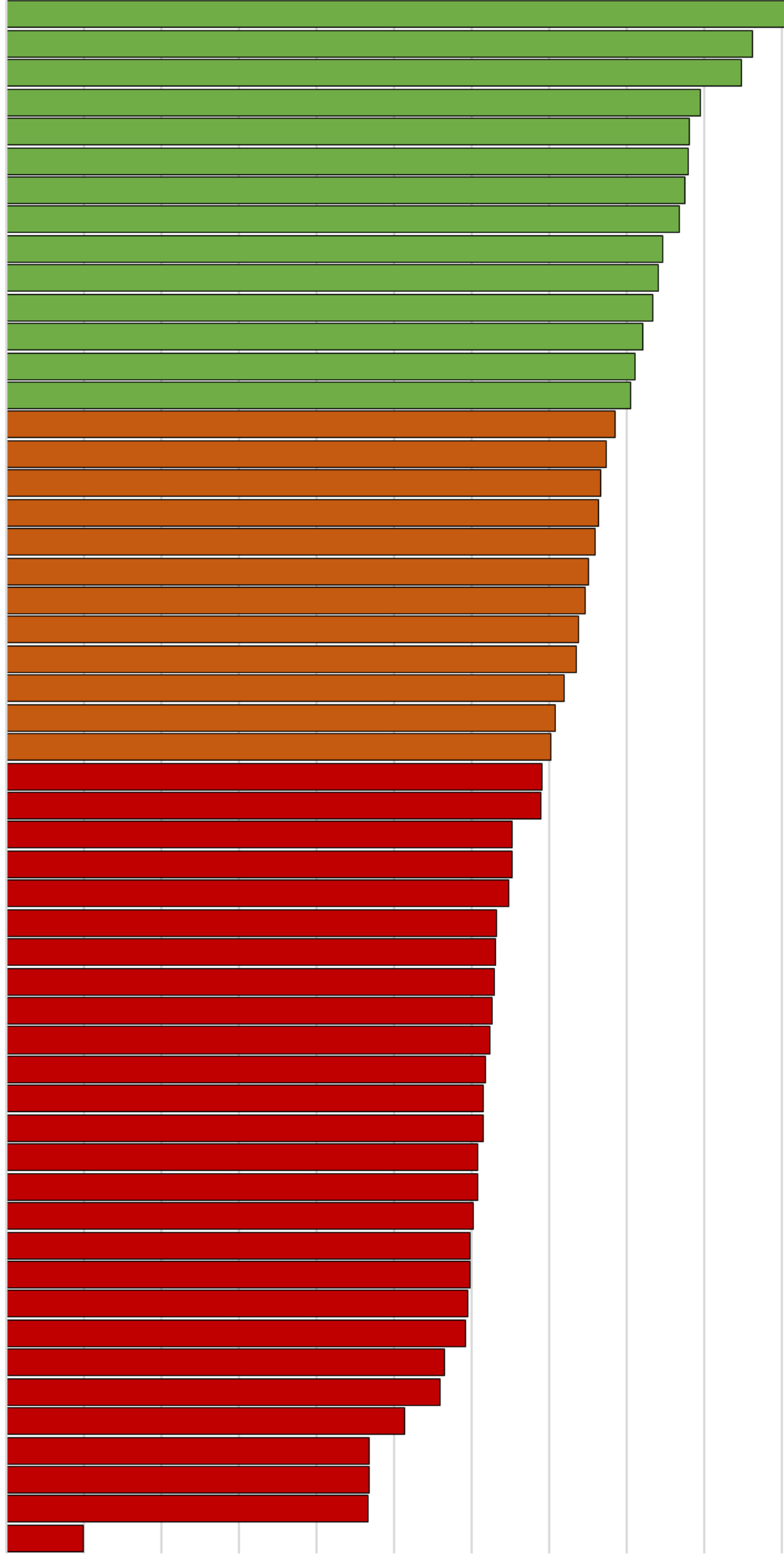

$\begin{array}{lll}0.0000001 & 0.000001 \quad 0.00001\end{array}$

$0.0001 \quad 0.001$

0.01

0.1

1

100

1000

Lung $\mathrm{Cmax} / \mathrm{EC}_{50}$ ratio (prediction) 


\section{Tables}

Table 1. Drugs investigated for SARS-CoV-2 antiviral activity and experimental overview

\begin{tabular}{|c|c|c|c|c|c|c|c|c|c|c|}
\hline Drug name & $\begin{array}{l}\text { Multiplicity } \\
\text { of Infection } \\
\text { (MOI) }\end{array}$ & Cell Type & Virus Strain & $\begin{array}{l}\text { Concentrati } \\
\text { on Range } \\
\text { Tested }\end{array}$ & $\begin{array}{c}\text { Viral } \\
\text { Quantificati } \\
\text { on }\end{array}$ & $\begin{array}{c}\text { Approved } \\
\text { clinical dose }\end{array}$ & Indication & $\begin{array}{c}\text { Population } \\
\text { in which PK } \\
\text { was } \\
\text { assessed }\end{array}$ & Ref & $\begin{array}{l}\text { Link to } \\
\text { regulatory } \\
\text { description }\end{array}$ \\
\hline Abemaciclib & 0.0125 & $\begin{array}{l}\text { Vero E6 cells } \\
\text { (ATCC CCL- } \\
\text { 81) }\end{array}$ & 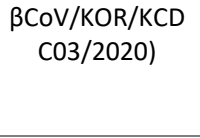 & $0.05-50 \mathrm{uM}$ & $\begin{array}{l}\text { Immunofluo } \\
\text { rescence }\end{array}$ & $200 \mathrm{mg}$ BID & Cancer & $\begin{array}{l}\text { Patients with } \\
\text { BC, NSCLC, } \\
\text { other solid } \\
\text { tumours }\end{array}$ & [28] & $\begin{array}{l}\frac{h \text { https://www.acc }}{\text { essdata.fda.gov/ }} \\
\frac{\text { drugsatfda docs/ } /}{\text { label/2017/2087 }} \\
\underline{16 s 0001 b l . p d f}\end{array}$ \\
\hline Alprostadil & 0.002 & $\begin{array}{c}\text { VeroE6 } \\
\text { (ATCC CRL- } \\
1586)\end{array}$ & BavPat1 & $\begin{array}{c}0.6 \mu \mathrm{M} \text { to } \\
40 \mu \mathrm{M}\end{array}$ & RT-PCR & $\begin{array}{l}360 \text { ug QD } \\
\text { (up to } 500 \\
\text { ug for single } \\
\text { topical use) }\end{array}$ & $\begin{array}{c}\text { Induce } \\
\text { vasodilatatio } \\
\text { n/Erectile } \\
\text { dysfunction }\end{array}$ & $\begin{array}{l}\text { Healthy } \\
\text { male } \\
\text { volunteers - } \\
\text { IV infusion }\end{array}$ & [26] & $\begin{array}{l}\frac{\text { https://www.acc }}{\text { essdata.fda.gov/ }} \\
\begin{array}{l}\text { drugsatfda docs/ } / \\
\text { label/2015/0206 } \\
\text { 49s023lbl.pdf }\end{array}\end{array}$ \\
\hline $\begin{array}{c}\text { Amodiaquine } \\
1\end{array}$ & 0.0125 & $\begin{array}{l}\text { Vero E6 cells } \\
\text { (ATCC CCL- } \\
\text { 81) }\end{array}$ & $\begin{array}{c}\beta C O V / K O R / K C D \\
C 03 / 2020)\end{array}$ & $0.05-50 \mathrm{uM}$ & $\begin{array}{l}\text { Immunofluo } \\
\text { rescence }\end{array}$ & $540 \mathrm{mg}$ QD & Malaria & $\begin{array}{c}\text { Healthy } \\
\text { male } \\
\text { Vietnamese } \\
\text { volunteers }\end{array}$ & [28] & 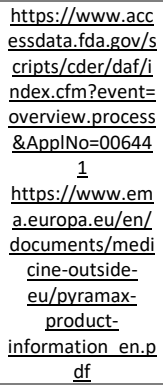 \\
\hline $\begin{array}{l}\text { Amodiaquine } \\
2\end{array}$ & 0.01 & Vero E6 cells & $\begin{array}{l}\text { WA-1 strain - } \\
\text { BEI \#NR-52281 }\end{array}$ & $0.4-50 \mathrm{uM}$ & $\begin{array}{c}\text { plaque assay } \\
\text { / TCID50/ } \\
\text { qRT-PCR }\end{array}$ & $\begin{array}{c}10 \mathrm{mg} / \mathrm{kg} \\
\text { (single dose) }\end{array}$ & Malaria & $\begin{array}{l}\text { Healthy } \\
\text { Volunteers }\end{array}$ & [23] & $\begin{array}{l}\text { https://www.acc } \\
\text { essdata.fda.gov/s } \\
\text { cripts/cder/daf/i } \\
\text { ndex.cfm?event= } \\
\text { overview.process } \\
\text { \&ApplNo=006444 }\end{array}$ \\
\hline $\begin{array}{c}\text { Amodiaquine } \\
3\end{array}$ & 0.01 & Vero E6 cells & $\begin{array}{l}\text { WA-1 strain - } \\
\text { BEI \#NR-52282 }\end{array}$ & $0.4-50 \mathrm{uM}$ & $\begin{array}{c}\text { plaque assay } \\
\text { / TCID50/ } \\
\text { qRT-PCR }\end{array}$ & $450 \mathrm{mg}$ QD & Malaria & $\begin{array}{c}\text { Healthy } \\
\text { Volunteers }\end{array}$ & [23] & 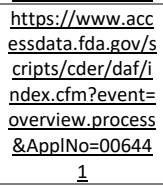 \\
\hline Amprenavir & 0.01 & $\begin{array}{l}\text { VeroE6/TMP } \\
\text { RSS2 }\end{array}$ & No info & $\begin{array}{c}0.01-1000 \\
\text { uM }\end{array}$ & RT-PCR & $\begin{array}{c}\text { 600mg twice } \\
\text { BID }\end{array}$ & HIV & $\begin{array}{c}\text { HIV-1 } \\
\text { infected } \\
\text { patients }\end{array}$ & [31] & 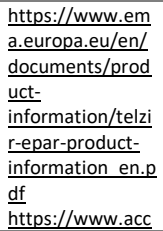 \\
\hline
\end{tabular}




\begin{tabular}{|c|c|c|c|c|c|c|c|c|c|c|}
\hline & & & & & & & & & & $\begin{array}{l}\text { essdata.fda.gov/ } \\
\text { drugsatfda docs } / \\
\text { label/2005/0210 } \\
\text { 07s0171bl.pdf }\end{array}$ \\
\hline $\begin{array}{c}\text { Anidulafungi } \\
n\end{array}$ & 0.0125 & $\begin{array}{l}\text { Vero E6 cells } \\
\text { (ATCC CCL- } \\
81 \text { ) }\end{array}$ & $\begin{array}{c}\beta C O V / K O R / K C D \\
C 03 / 2020)\end{array}$ & $0.05-50 \mathrm{uM}$ & $\begin{array}{l}\text { Immunofluo } \\
\text { rescence }\end{array}$ & $\begin{array}{c}\text { Loading of } \\
200 \mathrm{mg} \text { QD } \\
\text { and } \\
\text { subsequent } \\
100 \mathrm{mg} \text { QD }\end{array}$ & $\begin{array}{c}\text { Invasive } \\
\text { candidiasis/c } \\
\text { andidaemia }\end{array}$ & $\begin{array}{c}\text { Healthy } \\
\text { volunteers }\end{array}$ & [28] & 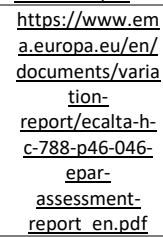 \\
\hline Atazanavir 1 & 0.01 & Vero E6 & $\begin{array}{l}\text { Brazil/RJ- } \\
\text { 314/2020 }\end{array}$ & $10-1000 \mu \mathrm{M}$ & RT-PCR & $\begin{array}{c}\text { 300/100 mg } \\
\text { OD (with } \\
\text { ritonavir) }\end{array}$ & $\begin{array}{c}\text { HIV-1 } \\
\text { infection }\end{array}$ & $\begin{array}{l}\text { Healthy } \\
\text { male } \\
\text { volunteers }\end{array}$ & [98] & $\begin{array}{l}\frac{\text { https://www.acc }}{\text { essdata.fda.gov/ }} \\
\text { drugsatfda docs/ } \\
\frac{\text { nda/2003/02156 }}{7 \text { reyataz toc.cf }} \\
\underline{m}\end{array}$ \\
\hline Atazanavir 2 & 0.01 & $\begin{array}{l}\text { VeroE6/TMP } \\
\text { RSS2 }\end{array}$ & No info & $\begin{array}{c}0.01-1000 \\
\text { uM }\end{array}$ & RT-PCR & $\begin{array}{c}\text { 300/100 mg } \\
\text { OD (with } \\
\text { ritonavir) }\end{array}$ & $\begin{array}{c}\text { HIV-1 } \\
\text { infection }\end{array}$ & $\begin{array}{l}\text { Healthy } \\
\text { male } \\
\text { volunteers }\end{array}$ & [31] & $\begin{array}{l}\frac{\text { https://www.acc }}{\text { essdata.fda.gov/ }} \\
\frac{\text { drugsatfda docs/ } / \text { dada }}{\text { nda/2003/02156 }} \\
\frac{7 \text { reyataz toc.cf }}{m}\end{array}$ \\
\hline Azithromycin & 0.002 & $\begin{array}{c}\text { VeroE6 } \\
\text { (ATCC CRL- } \\
1586 \text { ) }\end{array}$ & BavPat1 & $\begin{array}{c}0.6 \mu \mathrm{M} \text { to } \\
40 \mu \mathrm{M}\end{array}$ & RT-PCR & $500 \mathrm{mg}$ QD & $\begin{array}{l}\text { Used to } \\
\text { treat a range } \\
\text { of bacterial } \\
\text { infections }\end{array}$ & $\begin{array}{l}\text { Healthy } \\
\text { male } \\
\text { volunteers }\end{array}$ & [26] & 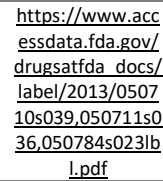 \\
\hline Baricitinib & 0.01 & Vero E6 cells & $\begin{array}{l}\text { WA-1 strain - } \\
\text { BEI \#NR-52283 }\end{array}$ & $0.4-50 \mathrm{uM}$ & $\begin{array}{c}\text { plaque assay } \\
\text { / TCID50/ } \\
\text { qRT-PCR }\end{array}$ & $20 \mathrm{mg}$ QD & $\begin{array}{l}\text { Rheumatoid } \\
\text { arthritis }\end{array}$ & $\begin{array}{c}\text { Healthy } \\
\text { Volunteers }\end{array}$ & [23] & $\begin{array}{l}\frac{\text { https:://www.acc }}{\text { essdata.fda.gov/ }} \\
\frac{\text { drugsatfda docs/ }}{\text { nda/2018/20792 }} \\
\frac{40 \text { rig1s000clinP }}{\text { harmR.pdf }}\end{array}$ \\
\hline Bazedoxifene & 0.0125 & $\begin{array}{l}\text { Vero E6 cells } \\
\text { (ATCC CCL- } \\
\text { 81) }\end{array}$ & $\begin{array}{c}\beta \mathrm{CoV} / \mathrm{KOR} / \mathrm{KCD} \\
\mathrm{C03} / 2020)\end{array}$ & $0.05-50 \mathrm{uM}$ & $\begin{array}{l}\text { Immunofluo } \\
\text { rescence }\end{array}$ & $40 \mathrm{mg}$ QD & $\begin{array}{c}\text { Treatment } \\
\text { of } \\
\text { osteoporosis } \\
\text { in } \\
\text { postmenopa } \\
\text { usal women }\end{array}$ & $\begin{array}{c}\text { Healthy } \\
\text { postmenopa } \\
\text { usal women }\end{array}$ & [23] & $\begin{array}{l}\frac{\text { httpss://www.acc }}{\text { essdata.fda.gov/ }} \\
\frac{\text { drugsatfda docs/ } /}{\text { label/2013/0222 }} \\
\frac{\text { 470rig1s0011bl.p }}{\text { df }}\end{array}$ \\
\hline Benztropine & 0.01 & Vero E6 cells & $\begin{array}{l}\text { WA-1 strain - } \\
\text { BEI \#NR-52284 }\end{array}$ & $0.4-50 \mathrm{uM}$ & $\begin{array}{c}\text { plaque assay } \\
\text { / TCID50/ } \\
\text { qRT-PCR }\end{array}$ & $1.5 \mathrm{mg} \mathrm{QD}$ & $\begin{array}{l}\text { Parkinson's } \\
\text { disease }\end{array}$ & $\begin{array}{l}\text { Healthy } \\
\text { Volunteers }\end{array}$ & [23] & $\begin{array}{l}\text { https://www.acc } \\
\text { essdata.fda.gov/s } \\
\text { cripts/cder/daf/i } \\
\text { ndex.cfm?event= } \\
\text { overview.process } \\
\text { \&ApplNo=04071 } \\
\underline{5}\end{array}$ \\
\hline Camostat & 0.0125 & $\begin{array}{l}\text { Vero E6 cells } \\
\text { (ATCC CCL- } \\
81 \text { ) }\end{array}$ & $\begin{array}{c}\beta \mathrm{COV} / \mathrm{KOR} / \mathrm{KCD} \\
\mathrm{C03} / 2020)\end{array}$ & $0.05-50 \mathrm{uM}$ & $\begin{array}{l}\text { Immunofluo } \\
\text { rescence }\end{array}$ & $200 \mathrm{mg}$ TID & Pancreatitis & $\begin{array}{c}\text { Can only find } \\
\text { single dose } \\
\text { PK }\end{array}$ & [23] & $\begin{array}{l}\text { https://www.acc } \\
\text { essdata.fda.gov/s/s } \\
\text { cripts/opdlisting/ } \\
\text { oopd/detailedlnd } \\
\text { ex.cfm?cfgridkey } \\
=338211\end{array}$ \\
\hline
\end{tabular}




\begin{tabular}{|c|c|c|c|c|c|c|c|c|c|c|}
\hline $\begin{array}{c}\text { Chloroquine } \\
1\end{array}$ & 0.05 & $\begin{array}{l}\text { Vero E6 cells } \\
\text { (ATCC-1586) }\end{array}$ & $\begin{array}{c}\text { Wuhan/WIV04/ } \\
2022\end{array}$ & $1-1000$ & $\begin{array}{l}\text { qRT-PCR/ NP } \\
\text { expression, } \\
\text { immunofluor } \\
\text { escence }\end{array}$ & $\begin{array}{c}1500 \mathrm{mg} \\
\text { over } 3 \text { days }\end{array}$ & Malaria & $\begin{array}{l}\text { Healthy Thai } \\
\text { subjects }\end{array}$ & [27] & $\begin{array}{l}\frac{\text { https://www.fda. }}{\text { gov/media/1365 }} \\
\text { 35/download }\end{array}$ \\
\hline $\begin{array}{c}\text { Chloroquine } \\
2\end{array}$ & 0.0125 & $\begin{array}{l}\text { Vero E6 cells } \\
\text { (ATCC CCL- } \\
81 \text { ) }\end{array}$ & $\begin{array}{c}\beta \mathrm{CoV} / \mathrm{KOR} / \mathrm{KCD} \\
\mathrm{C03} / 2020)\end{array}$ & $0.05-50 \mathrm{uM}$ & $\begin{array}{l}\text { Immunofluo } \\
\text { rescence }\end{array}$ & $\begin{array}{l}1500 \mathrm{mg} \\
\text { over } 3 \text { days }\end{array}$ & Malaria & $\begin{array}{l}\text { Healthy Thai } \\
\text { subjects }\end{array}$ & [28] & $\begin{array}{l}\frac{\text { https://www.fda. }}{\text { gov/media/1365 }} \\
\text { 35/download }\end{array}$ \\
\hline $\begin{array}{c}\text { Chloroquine } \\
\mathbf{3}\end{array}$ & 0.05 & $\begin{array}{l}\text { Vero E6 cells } \\
\text { (ATCC CCL- } \\
81 \text { ) }\end{array}$ & $\begin{array}{c}\beta \mathrm{COV} / \mathrm{KOR} / \mathrm{KCD} \\
\mathrm{C03} / 2020)\end{array}$ & $0.05-50 \mathrm{uM}$ & CPE & $\begin{array}{l}1500 \mathrm{mg} \\
\text { over } 3 \text { days }\end{array}$ & Malaria & $\begin{array}{l}\text { Healthy Thai } \\
\text { subjects }\end{array}$ & [28] & 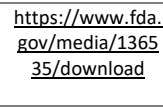 \\
\hline $\begin{array}{c}\text { Chloroquine } \\
4\end{array}$ & 0.01 & Vero cells & $\begin{array}{c}\text { C-Tan-nCoV } \\
\text { Wuhan strain } \\
01\end{array}$ & $\begin{array}{c}0.032-100 \\
\text { uM }\end{array}$ & RT-PCR & $\begin{array}{l}1500 \mathrm{mg} \\
\text { over } 3 \text { days }\end{array}$ & Malaria & $\begin{array}{l}\text { Healthy Thai } \\
\text { subjects }\end{array}$ & [34] & 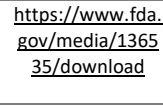 \\
\hline $\begin{array}{c}\text { Chloroquine } \\
5\end{array}$ & 0.01 & Vero E6 cells & $\begin{array}{l}\text { WA-1 strain - } \\
\text { BEI \#NR-52285 }\end{array}$ & $0.4-50 \mathrm{uM}$ & $\begin{array}{c}\text { plaque assay } \\
\text { / TCID50/ } \\
\text { qRT-PCR }\end{array}$ & $\begin{array}{l}1500 \mathrm{mg} \\
\text { over } 3 \text { days }\end{array}$ & Malaria & $\begin{array}{l}\text { Healthy Thai } \\
\text { subjects }\end{array}$ & [23] & $\begin{array}{l}\frac{\text { https://www.fda. }}{\text { gov//medial/1365 }} \\
\text { 35/dowload }\end{array}$ \\
\hline $\begin{array}{l}\text { Chlorpromazi } \\
\text { ne }\end{array}$ & 0.01 & Vero E6 cells & $\begin{array}{l}\text { WA-1 strain - } \\
\text { BEI \#NR-52286 }\end{array}$ & $0.4-50 \mathrm{uM}$ & $\begin{array}{c}\text { plaque assay } \\
\text { / TCID50/ } \\
\text { qRT-PCR }\end{array}$ & $\begin{array}{c}100 \mathrm{mg} \\
\text { (single dose) }\end{array}$ & $\begin{array}{c}\text { Antipsychoti } \\
\text { c }\end{array}$ & $\begin{array}{l}\text { Healthy } \\
\text { male } \\
\text { volunteers }\end{array}$ & [23] & 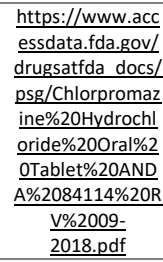 \\
\hline Ciclesonide & 0.0125 & $\begin{array}{l}\text { Vero E6 cells } \\
\text { (ATCC CCL- } \\
81 \text { ) }\end{array}$ & $\begin{array}{c}\beta \mathrm{COV} / \mathrm{KOR} / \mathrm{KCD} \\
\mathrm{C03} / 2020)\end{array}$ & $0.05-50$ uM & $\begin{array}{l}\text { Immunofluo } \\
\text { rescence }\end{array}$ & $\begin{array}{c}360 \mu \mathrm{g} \text { QD } \\
\text { (inhaled } \\
\text { only) }\end{array}$ & $\begin{array}{l}\text { Treatment } \\
\text { of asthma }\end{array}$ & $\begin{array}{c}37 \text { pediatric } \\
\text { patients with } \\
\text { Asthma }\end{array}$ & [28] & $\frac{\frac{h \text { htps://www.fda. }}{\text { gov/media/7147 }}}{\text { 8/download }}$ \\
\hline $\begin{array}{c}\text { Clomipramin } \\
\text { e }\end{array}$ & 0.01 & Vero E6 cells & $\begin{array}{l}\text { WA-1 strain - } \\
\text { BEI \#NR-52287 }\end{array}$ & $0.4-50 \mathrm{uM}$ & $\begin{array}{c}\text { plaque assay } \\
\text { / TCID50/ } \\
\text { qRT-PCR }\end{array}$ & $150 \mathrm{mg}$ QD & $\begin{array}{c}\text { Treatment } \\
\text { of } \\
\text { Obsessive- } \\
\text { Compulsive } \\
\text { Disorder }\end{array}$ & $\begin{array}{l}\text { Healthy } \\
\text { volunteers }\end{array}$ & [23] & $\begin{array}{l}\frac{\text { https: //www.acc }}{\text { essdata.fda.gov/ } /} \\
\frac{\text { drugsatfda docs/ } / \text { label/2012/0199 }}{\underline{\text { 065037lbl.pdf }}}\end{array}$ \\
\hline Cyclosporine & 0.0125 & $\begin{array}{l}\text { Vero E6 cells } \\
\text { (ATCC CCL- } \\
\text { 81) }\end{array}$ & $\begin{array}{c}\beta \mathrm{CoV} / \mathrm{KOR} / \mathrm{KCD} \\
\mathrm{C03} / 2020)\end{array}$ & $0.05-50 \mathrm{uM}$ & $\begin{array}{l}\text { Immunofluo } \\
\text { rescence }\end{array}$ & $100 \mathrm{mg}$ QD & $\begin{array}{l}\text { Immunosup } \\
\text { pressant }\end{array}$ & $\begin{array}{l}\text { Healthy } \\
\text { volunteers }\end{array}$ & [28] & 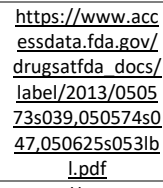 \\
\hline Darunavir & 0.01 & $\begin{array}{l}\text { VeroE6/TMP } \\
\text { RSS2 }\end{array}$ & No info & $\begin{array}{c}0.01-1000 \\
\text { uM }\end{array}$ & RT-PCR & $\begin{array}{c}600 / 100 \mathrm{mg} \\
\text { BID (with } \\
\text { ritonavir) }\end{array}$ & HIV & $\begin{array}{c}\text { Adult } \\
\text { patients } \\
\text { Coinfected } \\
\text { with } \\
\text { Hepatitis C } \\
\text { and HIV }\end{array}$ & [31] & $\begin{array}{l}\frac{\text { https://www.acc }}{\text { essdata.fda.gov/ }} \\
\frac{\text { drugsatfda docs/ } /}{\text { label/2012/0219 }} \\
\underline{76 \text { s } 0211 \mathrm{lbl} . \text { pdf }}\end{array}$ \\
\hline
\end{tabular}




\begin{tabular}{|c|c|c|c|c|c|c|c|c|c|c|}
\hline Digitoxin & 0.0125 & $\begin{array}{l}\text { Vero E6 cells } \\
\text { (ATCC CCL- } \\
\text { 81) }\end{array}$ & $\begin{array}{c}\beta \mathrm{COV} / \mathrm{KOR} / \mathrm{KCD} \\
\mathrm{C03} / 2020)\end{array}$ & $0.05-50 \mathrm{uM}$ & $\begin{array}{l}\text { Immunofluo } \\
\text { rescence }\end{array}$ & $\begin{array}{c}0.56 \mathrm{mg} \\
\text { (single dose) }\end{array}$ & $\begin{array}{l}\text { Cardiovascul } \\
\text { ar/Cancer }\end{array}$ & $\begin{array}{c}\text { Healthy } \\
\text { volunteers }\end{array}$ & [28] & 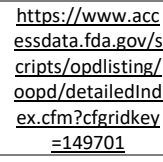 \\
\hline Digoxin & 0.0125 & $\begin{array}{l}\text { Vero E6 cells } \\
\text { (ATCC CCL- } \\
\text { 81) }\end{array}$ & $\begin{array}{c}\beta \mathrm{COV} / \mathrm{KOR} / \mathrm{KCD} \\
\mathrm{C03} / 2020)\end{array}$ & $0.05-50 \mathrm{uM}$ & $\begin{array}{l}\text { Immunofluo } \\
\text { rescence }\end{array}$ & $\begin{array}{l}2 \mathrm{mg} \text { loading } \\
\text { QD then } 0.5 \\
\mathrm{mg} Q \mathrm{QD}\end{array}$ & $\begin{array}{c}\text { Cardiovascul } \\
\text { ar }\end{array}$ & $\begin{array}{l}\text { Healthy } \\
\text { volunteers }\end{array}$ & [28] & $\begin{array}{l}\frac{\text { https://www.acc }}{\text { essdata.fda.gov/ }} \\
\text { drugsatfda docs/ } \\
\text { label/2016/0204 } \\
\underline{05 \text { 05013lbl.pdf }}\end{array}$ \\
\hline Dolutegravir & 0.002 & $\begin{array}{c}\text { VeroE6 } \\
\text { (ATCC CRL- } \\
1586)\end{array}$ & BavPat1 & $\begin{array}{c}0.6 \mu \mathrm{M} \text { to } \\
40 \mu \mathrm{M}\end{array}$ & RT-PCR & $50 \mathrm{mg}$ BID & HIV & $\begin{array}{c}\text { Healthy } \\
\text { volunteers }\end{array}$ & [26] & $\begin{array}{l}\frac{\text { https://www.acc }}{\text { essdata.fda.gov/ }} \\
\text { drugsatfda docs/ } \\
\frac{\text { label/2013/2047 }}{\text { golbl.pdf }}\end{array}$ \\
\hline Ebselen & 0.05 & $\begin{array}{l}\text { Vero Cells } \\
\text { (ATCC) }\end{array}$ & No info & $0.4-100 u m$ & $\begin{array}{l}\text { Plaque- } \\
\text { reduction } \\
\text { assay }\end{array}$ & $\begin{array}{c}1600 \mathrm{mg} \\
\text { (single dose) }\end{array}$ & $\begin{array}{l}\text { Prevention } \\
\text { and } \\
\text { treatment of } \\
\text { noise } \\
\text { induced } \\
\text { hearing loss }\end{array}$ & $\begin{array}{l}\text { Healthy } \\
\text { volunteers }\end{array}$ & [33] & In development \\
\hline Eltrombopag & 0.0125 & $\begin{array}{l}\text { Vero E6 cells } \\
\text { (ATCC CCL- } \\
\text { 81) }\end{array}$ & $\begin{array}{c}\beta \mathrm{COV} / \mathrm{KOR} / \mathrm{KCD} \\
\mathrm{C03} / 2020)\end{array}$ & $0.05-50 \mathrm{uM}$ & $\begin{array}{l}\text { Immunofluo } \\
\text { rescence }\end{array}$ & $75 \mathrm{mg}$ QD & $\begin{array}{l}\text { Idiopathic } \\
\text { thrombocyto } \\
\text { penic } \\
\text { purpura } \\
\text { (ITP) }\end{array}$ & $\begin{array}{l}\text { Healthy } \\
\text { adult } \\
\text { Japanese } \\
\text { males }\end{array}$ & [28] & $\begin{array}{l}\frac{\text { https://www.acc }}{\text { essdata.fda.gov/ }} \\
\frac{\text { drugsattda docs/ } /}{\text { label/2017/2070 }} \\
\underline{2750031 b l . p d f}\end{array}$ \\
\hline Emetine & 0.02 & $\begin{array}{c}\text { VeroE6 } \\
\text { (ATCC CRL- } \\
1586)\end{array}$ & $\begin{array}{c}\text { BetaCoV/Hong } \\
\text { Kong/VM20001 } \\
\text { 061/2020, }\end{array}$ & No info & $\begin{array}{c}\text { TCID50 } \\
\text { assay/ qRT- } \\
\text { PCR }\end{array}$ & $\begin{array}{c}30 \mathrm{ml} \text { syrup } \\
\text { of Ipecac } \\
\text { (single dose) }\end{array}$ & $\begin{array}{c}\text { Not } \\
\text { approved }\end{array}$ & $\begin{array}{c}\text { Healthy } \\
\text { volunteers, } \\
\text { aged } 18-45\end{array}$ & [35] & - \\
\hline Favipiravir & 0.05 & $\begin{array}{l}\text { Vero E6 cells } \\
\text { (ATCC-1586) }\end{array}$ & $\begin{array}{c}\text { Wuhan/WIV04/ } \\
2019\end{array}$ & $1-1000$ & $\begin{array}{l}\text { qRT-PCR/ NP } \\
\text { expression, } \\
\text { immunofluor } \\
\text { escence }\end{array}$ & 600 mg BID & Ebola & $\begin{array}{l}\text { Healthy } \\
\text { volunteers }\end{array}$ & [27] & $\begin{array}{l}\text { Not FDA } \\
\text { approved }\end{array}$ \\
\hline Fluphenazine & 0.01 & Vero E6 cells & $\begin{array}{l}\text { WA-1 strain - } \\
\text { BEI \#NR-52288 }\end{array}$ & $0.4-50 \mathrm{uM}$ & $\begin{array}{l}\text { plaque assay } \\
\text { / TCID50/ } \\
\text { qRT-PCR }\end{array}$ & $\begin{array}{c}25 \mathrm{mg} \mathrm{IM} \text { at } \\
\mathrm{SS}\end{array}$ & $\begin{array}{c}\text { Antipsychoti } \\
\text { c }\end{array}$ & $\begin{array}{c}\text { Patients } \\
\text { receiving } \\
\text { chronic } \\
\text { neuroleptic } \\
\text { maintenance }\end{array}$ & [23] & 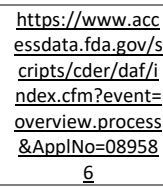 \\
\hline Fluspirilene & 0.01 & Vero E6 cells & $\begin{array}{l}\text { WA-1 strain - } \\
\text { BEI \#NR-52289 }\end{array}$ & $0.4-50$ uM & $\begin{array}{l}\text { plaque assay } \\
\text { / TCID50/ } \\
\text { qRT-PCR }\end{array}$ & $\begin{array}{c}2 \text { mg IM } \\
\text { dosed } \\
\text { weekly }\end{array}$ & $\begin{array}{c}\text { Antipsychoti } \\
\text { c }\end{array}$ & $\begin{array}{c}\text { Healthy } \\
\text { volunteers }\end{array}$ & [23] & Discontinued \\
\hline Gilteritinib & 0.0125 & $\begin{array}{l}\text { Vero E6 cells } \\
\text { (ATCC CCL- } \\
\text { 81) }\end{array}$ & $\begin{array}{c}\beta \mathrm{CoV} / \mathrm{KOR} / \mathrm{KCD} \\
\mathrm{C03} / 2020)\end{array}$ & $0.05-50$ uM & $\begin{array}{l}\text { Immunofluo } \\
\text { rescence }\end{array}$ & $120 \mathrm{mg}$ QD & $\begin{array}{l}\text { Relapsed or } \\
\text { refractory } \\
\text { acute } \\
\text { myeloid } \\
\text { leukemia }\end{array}$ & $\begin{array}{l}\text { Patients with } \\
\text { relapsed or } \\
\text { refractory } \\
\text { AML }\end{array}$ & [28] & 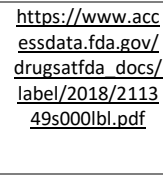 \\
\hline
\end{tabular}




\begin{tabular}{|c|c|c|c|c|c|c|c|c|c|c|}
\hline $\begin{array}{l}\text { Homoharring } \\
\text { tonine }\end{array}$ & 0.02 & $\begin{array}{c}\text { VeroE6 } \\
\text { (ATCC CRL- } \\
1586)\end{array}$ & $\begin{array}{c}\text { BetaCoV/Hong } \\
\text { Kong/VM20001 } \\
\text { 061/2020, }\end{array}$ & No info & $\begin{array}{l}\text { TCID50 } \\
\text { assay/ qRT- } \\
\text { PCR }\end{array}$ & $\begin{array}{c}1.25 \mathrm{mg} / \mathrm{m} 2 \\
\text { BID }\end{array}$ & $\begin{array}{l}\text { chronic } \\
\text { myeloid } \\
\text { leukemia }\end{array}$ & $\begin{array}{c}\text { Adult } \\
\text { patients with } \\
\text { a diagnosis } \\
\text { of relapsed } \\
\text { or refractory } \\
\text { CML }\end{array}$ & [35] & 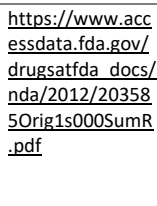 \\
\hline $\begin{array}{l}\text { Hydroxychlor } \\
\text { oquine } 1\end{array}$ & 0.01 & Vero cells & $\begin{array}{c}\text { C-Tan-nCoV } \\
\text { Wuhan strain } \\
01\end{array}$ & $\begin{array}{c}0.032-100 \\
\text { uM }\end{array}$ & RT-PCR & $400 \mathrm{mg}$ daily & $\begin{array}{l}\text { Rhuematoid } \\
\text { arthritis }\end{array}$ & $\begin{array}{l}\text { Patients with } \\
\text { rhuematoid } \\
\text { arthritis }\end{array}$ & [34] & 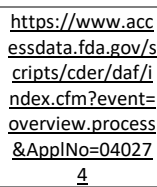 \\
\hline $\begin{array}{l}\text { Hydroxychlor } \\
\text { oquine } 2\end{array}$ & 0.01 & Vero E6 cells & $\begin{array}{l}\text { WA-1 strain - } \\
\text { BEI \#NR-52290 }\end{array}$ & $0.4-50$ uM & $\begin{array}{l}\text { plaque assay } \\
\text { / TCID50/ } \\
\text { qRT-PCR }\end{array}$ & 400mg daily & $\begin{array}{c}\text { Rheumatoid } \\
\text { arthritis }\end{array}$ & $\begin{array}{c}\text { Patients with } \\
\text { rhuematoid } \\
\text { arthritis }\end{array}$ & [23] & 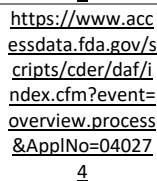 \\
\hline $\begin{array}{l}\text { Hydroxyprog } \\
\text { esterone }\end{array}$ & 0.0125 & $\begin{array}{l}\text { Vero E6 cells } \\
\text { (ATCC CCL- } \\
81 \text { ) }\end{array}$ & $\begin{array}{c}\beta \mathrm{CoV} / \mathrm{KOR} / \mathrm{KCD} \\
\mathrm{C03} / 2020)\end{array}$ & $0.05-50$ uM & $\begin{array}{l}\text { Immunofluo } \\
\text { rescence }\end{array}$ & $\begin{array}{c}250 \mathrm{mg} \mathrm{IM} \\
\text { (single dose) }\end{array}$ & $\begin{array}{l}\text { Reduces the } \\
\text { rate of } \\
\text { recurrent } \\
\text { preterm } \\
\text { birth }\end{array}$ & $\begin{array}{l}\text { Pregnant } \\
\text { women }\end{array}$ & [28] & $\frac{\text { https://www.fda. }}{\text { gov/media/1320 }}$ \\
\hline Imatinib & 0.01 & Vero E6 cells & $\begin{array}{l}\text { WA-1 strain - } \\
\text { BEI \#NR-52291 }\end{array}$ & $0.4-50 \mathrm{uM}$ & $\begin{array}{l}\text { plaque assay } \\
\text { / TCID50/ } \\
\text { qRT-PCR }\end{array}$ & $400 \mathrm{mg}$ BID & Cancer & $\begin{array}{l}\text { Healthy } \\
\text { volunteers }\end{array}$ & [23] & $\begin{array}{l}\frac{\text { https://www.acc }}{\text { essdata.fda.gov/ }} \\
\frac{\text { drugsatfda docs/ }}{\text { dabel/2008/0215 }} \\
\frac{\text { l8s024lbl.pdf }}{88024}\end{array}$ \\
\hline Indinavir & 0.01 & $\begin{array}{l}\text { VeroE6/TMP } \\
\text { RSS2 }\end{array}$ & No info & $\begin{array}{l}0.01-1000 \\
\text { uM }\end{array}$ & RT-PCR & $800 \mathrm{mg}$ TID & $\begin{array}{c}\text { HIV-1 } \\
\text { infection }\end{array}$ & $\begin{array}{l}\text { HIV-1 } \\
\text { infected } \\
\text { patients }\end{array}$ & [31] & 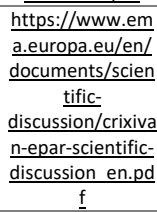 \\
\hline $\begin{array}{c}\text { Indomethaci } \\
n\end{array}$ & $\begin{array}{c}5 \mathrm{ng} \\
\text { pseudotype } \\
\text { d virus }\end{array}$ & Vero E6 & $\begin{array}{l}\text { cDNA used to } \\
\text { create } \\
\text { pseudotyped } \\
\text { virus, GenBank: } \\
\text { MN908947.3 }\end{array}$ & $0.1-500 \mathrm{uM}$ & $\begin{array}{c}\text { Luciferase } \\
\text { labelled }\end{array}$ & $50 \mathrm{mg}$ TID & $\begin{array}{c}\text { acute } \\
\text { painful } \\
\text { shoulder } \\
\text { (bursitis } \\
\text { and/or } \\
\text { tendinitis) }\end{array}$ & $\begin{array}{l}\text { Healthy } \\
\text { male } \\
\text { volunteers } \\
20-32 \text { yrs, } \\
\text { mostly } \\
\text { Caucasian }\end{array}$ & [29] & $\begin{array}{l}\frac{h_{\text {https://www.acc }}}{\text { essdata.fda.gov/ }} \\
\text { drugsatfda docs/ } \\
\frac{\text { label/2019/0160 }}{59 \text { s100lbl.pdf }}\end{array}$ \\
\hline Ivacaftor & 0.0125 & $\begin{array}{l}\text { Vero E6 cells } \\
\text { (ATCC CCL- } \\
\text { 81) }\end{array}$ & $\begin{array}{c}\beta \mathrm{CoV} / \mathrm{KOR} / \mathrm{KCD} \\
\mathrm{C03/2020)}\end{array}$ & $0.05-50$ uM & $\begin{array}{l}\text { Immunofluo } \\
\text { rescence }\end{array}$ & $150 \mathrm{mg}$ BID & $\begin{array}{l}\text { Cystic } \\
\text { fibrosis }\end{array}$ & $\begin{array}{c}\text { Healthy } \\
\text { volunteers }\end{array}$ & [28] & 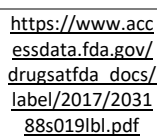 \\
\hline Ivermectin & 0.1 & Vero/hSLAM & $\begin{array}{l}\text { Australia/VIC01 } \\
\text { /2020 isolate) }\end{array}$ & $0.1-10$ uM & RT-PCR & $\begin{array}{c}\text { 200microg/K } \\
\text { g (single } \\
\text { dose) }\end{array}$ & $\begin{array}{l}\text { Strongyloidia } \\
\text { sis }\end{array}$ & $\begin{array}{l}\text { Healthy } \\
\text { volunteers } \\
\text { (mainly } \\
\text { male) }\end{array}$ & [36] & $\begin{array}{l}\text { https://www.acc } \\
\text { essdata.fda.gov/ } \\
\text { drugsatfda_docs/ } \\
\text { label/2008/0507 } \\
\text { 42s022lbl.pdf }\end{array}$ \\
\hline
\end{tabular}




\begin{tabular}{|c|c|c|c|c|c|c|c|c|c|c|}
\hline Loperamide & 0.0125 & $\begin{array}{l}\text { Vero E6 cells } \\
\text { (ATCC CCL- } \\
\text { 81) }\end{array}$ & $\begin{array}{c}\beta \mathrm{COV} / \mathrm{KOR} / \mathrm{KCD} \\
\mathrm{C03} / 2020)\end{array}$ & $0.05-50 \mathrm{uM}$ & $\begin{array}{l}\text { Immunofluo } \\
\text { rescence }\end{array}$ & $\begin{array}{c}8 \mathrm{mg} \text { (single } \\
\text { dose) }\end{array}$ & $\begin{array}{c}\text { Anti- } \\
\text { diarrhoeal } \\
\text { medication }\end{array}$ & $\begin{array}{c}\text { Healthy } \\
\text { Malaysian } \\
\text { male } \\
\text { volunteers } \\
\text { aged 21-55 }\end{array}$ & [28] & $\begin{array}{l}\frac{\text { https://www.acc }}{\text { essdata.fda.gov/ } /} \\
\frac{\text { drugsatfda docs/ } /}{\text { label/2016/017 }} \\
\underline{94 \text { s0521bl.pdf }}\end{array}$ \\
\hline Lopinavir 1 & 0.01 & $\begin{array}{l}\text { VeroE6/TMP } \\
\text { RSS2 }\end{array}$ & No info & $\begin{array}{c}0.01-1000 \\
\text { uM }\end{array}$ & RT-PCR & $\begin{array}{l}400 / 100 \mathrm{mg} \\
\text { Kaletra BID }\end{array}$ & HIV & $\begin{array}{l}\text { Healthy } \\
\text { male } \\
\text { volunteers }\end{array}$ & [31] & $\begin{array}{l}\frac{\text { https://www.acc }}{\text { essdata.fda.gov/ }} \\
\text { drugsatfda docs/ } \\
\frac{\text { nda/2000/21- }}{226 \text { Kaletra.cfm }}\end{array}$ \\
\hline Lopinavir 2 & 0.0125 & $\begin{array}{l}\text { Vero E6 cells } \\
\text { (ATCC CCL- } \\
\text { 81) }\end{array}$ & $\begin{array}{c}\beta \mathrm{CoV} / \mathrm{KOR} / \mathrm{KCD} \\
\mathrm{C03} / 2020)\end{array}$ & $0.05-50 \mathrm{uM}$ & $\begin{array}{l}\text { Immunofluo } \\
\text { rescence }\end{array}$ & $\begin{array}{c}400 / 100 \mathrm{mg} \\
\text { Kaletra BID }\end{array}$ & HIV & $\begin{array}{l}\text { Healthy } \\
\text { male } \\
\text { volunteers }\end{array}$ & [28] & $\begin{array}{l}\text { https://www.acc } \\
\text { essdata.fda.gov/ } \\
\text { drugsatfda docs/ } \\
\text { nda/2000/21- } \\
2 \underline{226 \text { Kaletra.cfm }}\end{array}$ \\
\hline Lopinavir 3 & 0.05 & $\begin{array}{l}\text { Vero E6 cells } \\
\text { (ATCC CCL- } \\
\text { 81) }\end{array}$ & $\begin{array}{c}\beta \mathrm{CoV} / \mathrm{KOR} / \mathrm{KCD} \\
\mathrm{C03/2020)}\end{array}$ & $0.05-50 \mu \mathrm{M}$ & CPE & $\begin{array}{l}400 / 100 \mathrm{mg} \\
\text { Kaletra BID }\end{array}$ & HIV & $\begin{array}{l}\text { Healthy } \\
\text { male } \\
\text { volunteers }\end{array}$ & [28] & $\begin{array}{l}\frac{\text { https://www.acc }}{\text { essdata.fda.gov/ }} \\
\text { drugsatfda docs/ } \\
\text { nda/2000/21- } \\
226 \text { Kaletra.cfm } \\
\end{array}$ \\
\hline Mefloquine 1 & 0.0125 & $\begin{array}{l}\text { Vero E6 cells } \\
\text { (ATCC CCL- } \\
\text { 81) }\end{array}$ & $\begin{array}{c}\beta \mathrm{CoV} / \mathrm{KOR} / \mathrm{KCD} \\
\mathrm{C03} / 2020)\end{array}$ & $0.05-50 \mathrm{uM}$ & $\begin{array}{l}\text { Immunofluo } \\
\text { rescence }\end{array}$ & $250 \mathrm{mg}$ & Malaria & $\begin{array}{l}\text { Adult Thai } \\
\text { males with, } \\
17-48 \text { years }\end{array}$ & [28] & 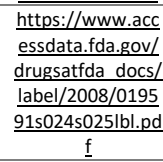 \\
\hline Mefloquine 2 & 0.01 & Vero E6 cells & $\begin{array}{l}\text { WA-1 strain - } \\
\text { BEI \#NR-52281 }\end{array}$ & $0.4-50 \mathrm{uM}$ & $\begin{array}{l}\text { plaque assay } \\
\text { / TCID50/ } \\
\text { qRT-PCR }\end{array}$ & $250 \mathrm{mg}$ & Malaria & $\begin{array}{l}\text { Adult Thai } \\
\text { males with, } \\
17-48 \text { years }\end{array}$ & [23] & 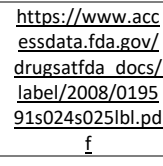 \\
\hline Merimepodib & 0.05 & Vero & $\begin{array}{c}\text { SARS-CoV-2 } \\
\text { USA-WA1/2020 }\end{array}$ & $\begin{array}{c}1493-4525 \\
\mathrm{ng} / \mathrm{ml}\end{array}$ & & $300 \mathrm{mg}$ TID & $\begin{array}{l}\mathrm{HCV} / \text { not } \\
\text { currently } \\
\text { approved }\end{array}$ & $\begin{array}{c}\mathrm{HCV}+ \\
\text { patients, } 18- \\
70 \text { years }\end{array}$ & [32] & \\
\hline Nelfinavir 1 & 0.01 & $\begin{array}{l}\text { VeroE6/TMP } \\
\text { RSS2 cells }\end{array}$ & No info & $\begin{array}{c}0.01-1000 \\
\text { uM }\end{array}$ & RT-PCR & $1250 \mathrm{mg}$ BID & HIV & $\begin{array}{c}\text { HIV+ } \\
\text { patients, } \\
62 \% \text { male, } \\
\text { mean age } 49\end{array}$ & [31] & $\begin{array}{l}\frac{\text { https://www.acc }}{\text { essdata.fda.gov/ }} \\
\text { drugsatfda docs/ } / \text { label/2005/0215 } \\
\frac{\text { 03s006llbl.pdf }}{\text { las }}\end{array}$ \\
\hline Nelfinavir 2 & 0.01 & $\begin{array}{l}\text { VeroE6/TMP } \\
\text { RSS2 }\end{array}$ & No info & $\begin{array}{c}0.01-1000 \\
\text { uM }\end{array}$ & RT-PCR & $1250 \mathrm{mg}$ BID & HIV & $\begin{array}{c}\text { HIV+ } \\
\text { patients, } \\
62 \% \text { male, } \\
\text { mean age } 49\end{array}$ & [29] & 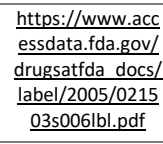 \\
\hline Niclosamide & 0.0125 & $\begin{array}{l}\text { Vero E6 cells } \\
\text { (ATCC CCL- } \\
\text { 81) }\end{array}$ & $\begin{array}{c}\beta \mathrm{COV} / \mathrm{KOR} / \mathrm{KCD} \\
\mathrm{C03} / 2020)\end{array}$ & $0.05-50 \mathrm{uM}$ & $\begin{array}{l}\text { Immunofluo } \\
\text { rescenc }\end{array}$ & $2000 \mathrm{mg}$ OD & Anthelmintic & $\begin{array}{l}\text { Adult male, } \\
\text { prostate } \\
\text { cancer } \\
\text { patient trial, } \\
\text { aged } 60-84\end{array}$ & [28] & $\frac{\frac{\text { https://www.fda. }}{\text { gov/media/9635 }}}{\underline{2 / \text { download }}}$ \\
\hline Nitazoxanide & 0.05 & $\begin{array}{l}\text { Vero E6 cells } \\
\text { (ATCC-1586) }\end{array}$ & $\begin{array}{c}\text { Wuhan/WIV04/ } \\
2020\end{array}$ & $0.1-100$ & $\begin{array}{l}\text { qRT-PCR/ NP } \\
\text { expression, } \\
\text { immunofluor } \\
\text { escence }\end{array}$ & $500 \mathrm{mg}$ BID & $\begin{array}{l}\text { Treatment } \\
\text { of diarrhoea } \\
\text { caused by }\end{array}$ & $\begin{array}{c}\text { Healthy } \\
\text { male } \\
\text { volunteers, } \\
\text { aged } 25-45\end{array}$ & [27] & 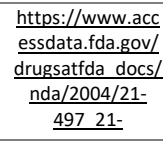 \\
\hline
\end{tabular}




\begin{tabular}{|c|c|c|c|c|c|c|c|c|c|c|}
\hline & & & & & & & $\begin{array}{l}\text { Giardia } \\
\text { lamblia }\end{array}$ & & & $\frac{4985001 \text { Alinia.c }}{\mathrm{fm}}$ \\
\hline Omeprazole & 0.002 & $\begin{array}{c}\text { VeroE6 } \\
\text { (ATCC CRL- } \\
\text { 1586) }\end{array}$ & BavPat1 & $\begin{array}{c}0.6 \mu \mathrm{M} \text { to } \\
40 \mu \mathrm{M}\end{array}$ & RT-PCR & $40 \mathrm{mg}$ QD & Gastric Ulcer & $\begin{array}{c}\text { Adult, } \\
\text { female } \\
\text { caucasians, } \\
\text { mean age } 51\end{array}$ & [26] & Discontinued \\
\hline Opipramol & 0.002 & $\begin{array}{c}\text { VeroE6 } \\
\text { (ATCC CRL- } \\
\text { 1586) }\end{array}$ & BavPat1 & $\begin{array}{c}0.6 \mu \mathrm{M} \text { to } \\
40 \mu \mathrm{M}\end{array}$ & RT-PCR & $100 \mathrm{mg}$ TID & $\begin{array}{l}\text { Somatoform } \\
\text { disorders } \\
\text { and } \\
\text { generalised } \\
\text { anxiety } \\
\text { disorders }\end{array}$ & $\begin{array}{c}\text { Adult } \\
\text { healthy } \\
\text { volunteers, } \\
\text { aged } 22-32\end{array}$ & [26] & 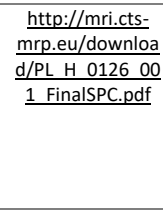 \\
\hline Oxprenolol & 0.002 & $\begin{array}{c}\text { VeroE6 } \\
\text { (ATCC CRL- } \\
1586 \text { ) }\end{array}$ & BavPat1 & $\begin{array}{c}0.6 \mu \mathrm{M} \text { to } \\
40 \mu \mathrm{M}\end{array}$ & RT-PCR & $320 \mathrm{mg}$ BID & $\begin{array}{c}\text { Hypertensio } \\
\mathrm{n} \text { and angina } \\
\text { pectoris }\end{array}$ & $\begin{array}{c}\text { Healthy } \\
\text { Volunteers }\end{array}$ & [26] & Discontinued \\
\hline Penciclovir & 0.05 & $\begin{array}{l}\text { Vero E6 cells } \\
\text { (ATCC-1586) }\end{array}$ & $\begin{array}{c}\text { Wuhan/WIV04/ } \\
2019\end{array}$ & $1-1000$ & $\begin{array}{l}\text { qRT-PCR/ NP } \\
\text { expression, } \\
\text { immunofluor } \\
\text { escence }\end{array}$ & $500 \mathrm{mg}$ TID & $\begin{array}{l}\text { Herpes } \\
\text { zoster }\end{array}$ & $\begin{array}{l}\text { Healthy } \\
\text { Volunteers }\end{array}$ & [27] & $\begin{array}{l}\frac{\text { https://www.acc }}{\text { essdata.fda.gov/ }} \\
\text { drugsatfda docs/ } \\
\frac{\text { label/2006/0203 }}{6350261 \mathrm{lbl} . p d f}\end{array}$ \\
\hline $\begin{array}{c}\text { Promethazin } \\
\text { e }\end{array}$ & 0.01 & Vero E6 cells & $\begin{array}{l}\text { WA-1 strain - } \\
\text { BEI \#NR-52292 }\end{array}$ & 0.4- $50 \mathrm{uM}$ & $\begin{array}{l}\text { plaque assay } \\
\text { / TCID50/ } \\
\text { qRT-PCR }\end{array}$ & $25 \mathrm{mg}$ BID & $\begin{array}{l}\text { Motion } \\
\text { Sickness }\end{array}$ & $\begin{array}{c}\text { Healthy } \\
\text { volunteers }\end{array}$ & [23] & $\begin{array}{c}\frac{\text { https://bnf.nice. }}{\text { org.uk/drug/pro }} \\
\text { methazine- } \\
\text { hydrochloride.ht } \\
\underline{\text { ml }}\end{array}$ \\
\hline Remdesivir 1 & 0.05 & $\begin{array}{l}\text { Vero E6 cells } \\
\text { (ATCC-1586) }\end{array}$ & $\begin{array}{c}\text { Wuhan/WIV04/ } \\
2022\end{array}$ & $0.1-100 \mathrm{uM}$ & $\begin{array}{l}\text { qRT-PCR/ NP } \\
\text { expression, } \\
\text { immunofluor } \\
\text { escence }\end{array}$ & $\begin{array}{c}200 \mathrm{mg} \text { IV } \\
\text { loading } \\
\text { dose, then } \\
100 \mathrm{mg} \text { IV } \\
\text { daily for 5- } \\
10 \text { days }\end{array}$ & covid-19 & $\begin{array}{c}\text { Healthy } \\
\text { Volunteers }\end{array}$ & [27] & 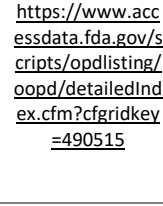 \\
\hline Remdesivir 2 & 0.002 & $\begin{array}{c}\text { VeroE6 } \\
\text { (ATCC CRL- } \\
1586 \text { ) }\end{array}$ & BavPat1 & $\begin{array}{c}0.6 \mu \mathrm{M} \text { to } \\
40 \mu \mathrm{M}\end{array}$ & RT-PCR & $\begin{array}{c}200 \mathrm{mg} \text { IV } \\
\text { loading } \\
\text { dose, then } \\
100 \mathrm{mg} \text { IV } \\
\text { daily for } 5- \\
10 \text { days }\end{array}$ & covid-19 & $\begin{array}{c}\text { Healthy } \\
\text { Volunteers }\end{array}$ & [31] & $\begin{array}{l}\text { https://www.acc } \\
\text { essdata.fda.gov/s } \\
\text { cripts/opdlisting/ } \\
\text { oopd/detaileddnd } \\
\text { ex.cfm?ffgridkey } \\
=490515\end{array}$ \\
\hline Remdesivir 3 & 0.05 & $\begin{array}{l}\text { Vero cells } \\
\text { (ATCC CCL- } \\
\text { 81) }\end{array}$ & $\begin{array}{c}\text { SARS-CoV-2 } \\
(\beta C O V / K O R / K C D \\
\text { C03/2020 }\end{array}$ & $0.05-50 \mu \mathrm{M}$ & CPE & $\begin{array}{c}200 \mathrm{mg} \text { IV } \\
\text { loading } \\
\text { dose, then } \\
100 \mathrm{mg} \text { IV } \\
\text { daily for } 5- \\
10 \text { days }\end{array}$ & covid-19 & $\begin{array}{c}\text { Healthy } \\
\text { Volunteers }\end{array}$ & [28] & $\begin{array}{l}\text { https://www.acc } \\
\text { essdata.fda.gov/s } \\
\text { cripts/opdlisting/ / } \\
\text { oopd/detailedlnd } \\
\text { ex.cfm?cfgridkey } \\
\text { =490515 }\end{array}$ \\
\hline Remdesivir 4 & 0.0125 & $\begin{array}{l}\text { Vero cells } \\
\text { (ATCC CCL- } \\
\text { 81) }\end{array}$ & $\begin{array}{c}\text { SARS-CoV-2 } \\
(\beta C O V / K O R / K C D \\
\text { C03/2019 }\end{array}$ & $0.05-50 \mu \mathrm{M}$ & $\begin{array}{l}\text { Immunofluo } \\
\text { rescence }\end{array}$ & $\begin{array}{c}200 \mathrm{mg} \text { IV } \\
\text { loading } \\
\text { dose, then } \\
100 \mathrm{mg} \text { IV }\end{array}$ & covid-19 & $\begin{array}{c}\text { Healthy } \\
\text { Volunteers }\end{array}$ & [28] & $\begin{array}{l}\text { https://www.acc } \\
\text { essdata.fda.gov/s/s } \\
\text { cripts/opdlisting/ } \\
\text { oopd/detailedlnd } \\
\text { ex.cfm?cfgridkey } \\
=490515\end{array}$ \\
\hline
\end{tabular}




\begin{tabular}{|c|c|c|c|c|c|c|c|c|c|c|}
\hline & & & & & & $\begin{array}{l}\text { daily for 5- } \\
10 \text { days }\end{array}$ & & & & \\
\hline Ribavirin & 0.05 & $\begin{array}{l}\text { Vero E6 cells } \\
\text { (ATCC-1586) }\end{array}$ & $\begin{array}{c}\text { Wuhan/WIV04/ } \\
2022\end{array}$ & $1-1000$ & $\begin{array}{l}\text { qRT-PCR/ NP } \\
\text { expression, } \\
\text { immunofluor } \\
\text { escence }\end{array}$ & $1200 \mathrm{mg}$ OD & $\mathrm{HCV}$ & $\begin{array}{c}\mathrm{HCV}+ \\
\text { patients }\end{array}$ & [27] & 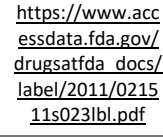 \\
\hline Ritonavir & 0.01 & $\begin{array}{l}\text { VeroE6/TMP } \\
\text { RSS2 }\end{array}$ & No info & $\begin{array}{c}0.01-1000 \\
\text { uM }\end{array}$ & RT-PCR & $600 \mathrm{mg}$ BID & HIV & HIV+ adults & [31] & $\begin{array}{l}\frac{\text { https://www.acc }}{\text { essdata.fda.gov/ }} \\
\text { drugsatfda docs/ } \\
\text { label/2011/0215 } \\
1150231 \mathrm{lbl} . p d f \\
\end{array}$ \\
\hline Saquinavir & 0.01 & $\begin{array}{l}\text { VeroE6/TMP } \\
\text { RSS2 }\end{array}$ & No info & $\begin{array}{c}0.01-1000 \\
\text { uM }\end{array}$ & RT-PCR & $\begin{array}{c}1000 / 100 \\
\text { mg BID (with } \\
\text { ritonavir) }\end{array}$ & HIV & $\begin{array}{l}\text { HIV+ males, } \\
83 \% \text { white, } \\
\text { mean age } 33\end{array}$ & [31] & 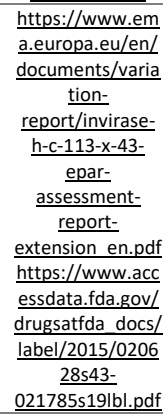 \\
\hline Sulfadoxine & 0.002 & $\begin{array}{c}\text { VeroE6 } \\
\text { (ATCC CRL- } \\
1586)\end{array}$ & BavPat1 & $\begin{array}{c}0.6 \mu \mathrm{M} \text { to } \\
40 \mu \mathrm{M}\end{array}$ & RT-PCR & $\begin{array}{c}\text { Sulfadoxine/ } \\
\text { pyrimethami } \\
\text { ne FDC } \\
(1500 / 75 \\
\mathrm{mg})\end{array}$ & Malaria & $\begin{array}{c}\text { Women } \\
\text { post-partum }\end{array}$ & [26] & $\begin{array}{c}\text { https://www.acc } \\
\text { essdata.fda.gov/ } \\
\frac{\text { drugsattda docs/ } /}{\text { label/2004/18555 }} \\
7 \text { slro15 fansidar } \\
\text { Ibl.pdf }\end{array}$ \\
\hline Tamoxifen & 0.01 & Vero E6 cells & $\begin{array}{l}\text { WA-1 strain - } \\
\text { BEI \#NR-52293 }\end{array}$ & $0.4-50 \mathrm{uM}$ & $\begin{array}{c}\text { plaque assay } \\
\text { / TCID50/ } \\
\text { qRT-PCR }\end{array}$ & 20mg BID & $\begin{array}{c}\text { Metastatic } \\
\text { breast } \\
\text { cancer }\end{array}$ & $\begin{array}{c}\text { Breast } \\
\text { Cancer } \\
\text { Patients }\end{array}$ & [23] & $\begin{array}{l}\frac{\text { https://www.acc }}{\text { essdata.fda.gov/ }} \\
\frac{\text { drugsatfda docs/ }}{\text { label/2005/1797 }} \\
\text { os053lbl.pdf }\end{array}$ \\
\hline Tipranavir & 0.01 & $\begin{array}{l}\text { VeroE6/TMP } \\
\text { RSS2 }\end{array}$ & No info & $\begin{array}{c}0.01-1000 \\
\text { uM }\end{array}$ & RT-PCR & $\begin{array}{c}500 / 200 \mathrm{mg} \\
\text { BID (with } \\
\text { ritonavir) }\end{array}$ & HIV & $\begin{array}{l}\text { Healthy } \\
\text { Male } \\
\text { Volunteers, } \\
\text { mainly } \\
\text { white, age } \\
21-58\end{array}$ & [31] & 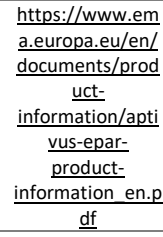 \\
\hline Toremifene 1 & 0.05 & $\begin{array}{l}\text { Vero E6 cells } \\
\text { (ATCC-1586) }\end{array}$ & $\begin{array}{c}\text { Wuhan/WIV04/ } \\
2023\end{array}$ & $1-1000$ & $\begin{array}{l}\text { qRT-PCR/NP } \\
\text { expression, } \\
\text { immunofluor } \\
\text { escence }\end{array}$ & $60 \mathrm{mg}$ OD & $\begin{array}{c}\text { Metastatic } \\
\text { breast } \\
\text { cancer }\end{array}$ & $\begin{array}{c}70 \text { patients } \\
\text { with Breast } \\
\text { cancer }\end{array}$ & [27] & $\begin{array}{l}\frac{\text { https://www.acc }}{\text { essdata.fda.gov/ }} \\
\text { drugsattda docs/ } / \\
\text { label/2018/0218 } \\
07 \text { s005lbl.pdf }\end{array}$ \\
\hline Toremifene 2 & 0.01 & Vero E6 cells & $\begin{array}{l}\text { WA-1 strain - } \\
\text { BEI \#NR-52294 }\end{array}$ & $0.4-50 \mathrm{uM}$ & $\begin{array}{c}\text { plaque assay } \\
\text { / TCID50/ } \\
\text { qRT-PCR }\end{array}$ & $60 \mathrm{mg}$ OD & $\begin{array}{c}\text { Metastatic } \\
\text { breast } \\
\text { cancer }\end{array}$ & $\begin{array}{c}70 \text { patients } \\
\text { with Breast } \\
\text { cancer }\end{array}$ & [23] & $\begin{array}{l}\frac{\text { https://www.acc }}{\text { essdata.fda.gov/ }} \\
\text { drugsatfda docs/ } \\
\text { label/2018/0218 } \\
\underline{0750051 \mathrm{lbl} . p \mathrm{df}}\end{array}$ \\
\hline
\end{tabular}


Prophylaxis/ treatment of

Healthy

$\begin{array}{ll}\text { influenza in subjects } & \end{array}$

1586)

Russia and

$$
\text { China }
$$


Table 2. Summary of the top leads identified

\begin{tabular}{|c|c|c|c|c|c|c|c|}
\hline Drug & Cmax: $\mathrm{EC}_{50}$ & Cmax: $\mathrm{EC}_{90}$ & Approval & Indications & $\begin{array}{c}\text { Route of } \\
\text { administration }\end{array}$ & Dosage & Ref \\
\hline $\begin{array}{c}\text { Atazanavir \& Ritonavir } \\
\text { REYATAZ }^{\circledR} \\
\text { (Bristol-Myers Squibb) }\end{array}$ & 3.643 & 0.728 & $\begin{array}{l}\text { EMA } \\
\text { FDA }\end{array}$ & HIV-1 & Oral & $300 / 100 \mathrm{mg}$ & {$[99,100]$} \\
\hline $\begin{array}{c}\text { Anidulafungin } \\
\text { Eraxis }^{\circledast} / \text { Ecalta }^{\circledR} \\
\text { (Pfizer) }\end{array}$ & 1.323 & 1.192 & $\begin{array}{l}\text { EMA } \\
\text { FDA }\end{array}$ & Invasive fungal infections & Intravenous Infusion & $\begin{array}{c}200 \mathrm{mg} Q \mathrm{QD}+ \\
100 \mathrm{mg} Q \mathrm{D}\end{array}$ & {$[101]$} \\
\hline $\begin{array}{c}\text { Chloroquine } \\
\text { Aralen }^{\circledast} \\
\text { (Sanofi Aventis) }\end{array}$ & 2.318 & 1.261 & FDA & $\begin{array}{l}\text { Malaria } \\
\text { Extraintestinal Amebiasis }\end{array}$ & Oral & $1500 \mathrm{mg}$ & {$[102]$} \\
\hline 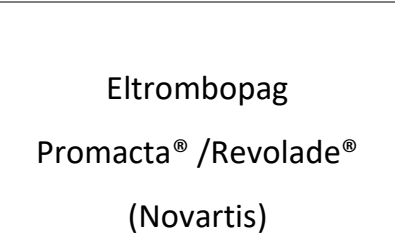 & 3.416 & 2.029 & $\begin{array}{l}\text { EMA } \\
\text { FDA }\end{array}$ & $\begin{array}{c}\text { Primary immune } \\
\text { thrombocytopenia } \\
\text { Acquired severe aplastic } \\
\text { anaemia }\end{array}$ & Oral & 75mg QD & [103] \\
\hline $\begin{array}{c}\text { Favipiravir } \\
\text { Avigan }^{\circledR} \\
\text { (Fujifilm Toyama Chemical } \\
\text { Co) }\end{array}$ & 6.326 & 2.469 & PMDA - Japan & Influenza & Oral & 600mg BID & [104] \\
\hline $\begin{array}{l}\text { Hydroxychloroquine } \\
\text { Plaquenil }^{\circledR}\end{array}$ & 3.598 & 0.101 & $\begin{array}{l}\text { EMA } \\
\text { FDA }\end{array}$ & Malaria & Oral & $400 \mathrm{mg}$ & [105] \\
\hline
\end{tabular}




\begin{tabular}{|c|c|c|c|c|c|c|c|}
\hline (Sanofi Aventis) & & & & & & & \\
\hline $\begin{array}{l}\text { Indomethacin } \\
\text { Indocin }^{\circledR} \\
\text { (Merck \& Co) }\end{array}$ & 5.366 & - & $\begin{array}{l}\text { EMA } \\
\text { FDA }\end{array}$ & Rheumatoid arthritis & Oral & 50mg TID & [106] \\
\hline $\begin{array}{l}\text { Lopinavir \& Ritonavir } \\
\qquad \text { Kaletra }^{\circledR} \\
\text { (AbbVie) }\end{array}$ & $2.660 / 1.671$ & $1.630 / 1.240$ & $\begin{array}{l}\text { EMA } \\
\text { FDA }\end{array}$ & HIV-1 & Oral & $\begin{array}{c}\text { 400/100mg } \\
\text { BID }\end{array}$ & [107] \\
\hline $\begin{array}{l}\text { Mefloquine } \\
\text { Lariam }^{\circledR} \\
\text { (Roche) }\end{array}$ & 1.350 & 1.284 & $\begin{array}{l}\text { EMA } \\
\text { FDA }\end{array}$ & Malaria & Oral & $250 \mathrm{mg}$ & [108] \\
\hline $\begin{array}{c}\text { Merimepodib } \\
\text { (Vertex Pharmaceuticals) }\end{array}$ & 1.629 & 0.638 & $\begin{array}{l}\text { Not clinically } \\
\text { approved }\end{array}$ & $\mathrm{HCV}$ & Oral & $300 \mathrm{mg}$ TID & [109] \\
\hline $\begin{array}{c}\text { Nelfinavir } \\
\text { VIRACEPT }^{\circledR} \\
\text { (Roche) }\end{array}$ & $5.849 / 2.287$ & 3.755 & $\begin{array}{l}\text { EMA } \\
\text { FDA }\end{array}$ & HIV-1 & Oral & $1250 \mathrm{mg}$ BID & [110] \\
\hline $\begin{array}{l}\text { Niclosamide } \\
\text { Yomesan }^{\circledR} \\
\text { (Bayer) }\end{array}$ & 8.286 & 4.936 & $\begin{array}{l}\text { EMA } \\
\text { FDA }\end{array}$ & Infestation with tapeworms & Oral & $2000 \mathrm{mg}$ & [111] \\
\hline $\begin{array}{c}\text { Nitazoxanide } \\
\text { Alinia }^{\circledR} \\
\text { (Romark Pharmaceuticals) }\end{array}$ & 13.823 & 6.315 & FDA & $\begin{array}{c}\text { Diarrhoea caused by Giardia } \\
\text { lamblia or Cryptosporidium } \\
\text { parvum }\end{array}$ & Oral & $\begin{array}{c}1000- \\
\text { 2000mg BID }\end{array}$ & [112] \\
\hline $\begin{array}{l}\text { Remdesivir } \\
\text { (Gilead) }\end{array}$ & $5.603 / 2.614$ & $3.755 / 1.712$ & $\begin{array}{l}\text { *Not clinically } \\
\text { approved }\end{array}$ & Ebola & Intravenous & $\begin{array}{l}200 \mathrm{mg}+ \\
100 \mathrm{mg}\end{array}$ & {$[27]$} \\
\hline Ritonavir & 1.800 & & EMA & HIV-1 & Oral & $600 \mathrm{mg}$ & [113] \\
\hline
\end{tabular}




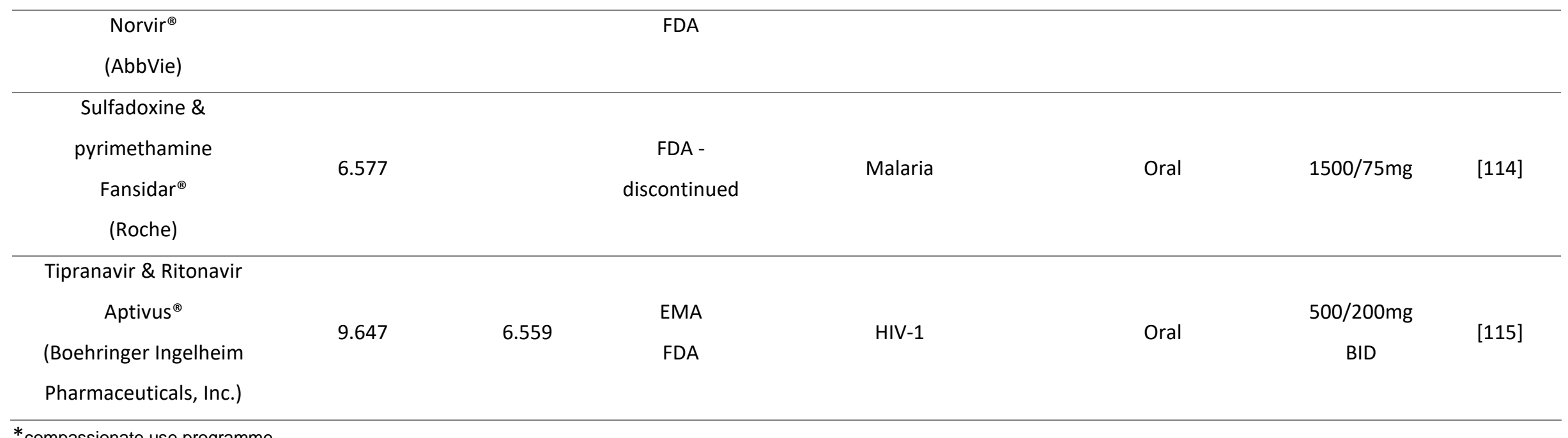

* compassionate use programme 